\title{
متطلبات تحقيق جودة المناخ التنظيمي بمؤسسات رياض الأطفال
}

$$
\text { إعراد }
$$

د/أميرة أحمد محمد حسن رضوان

$$
\text { إشرافـ }
$$

$$
\begin{aligned}
& \text { أ.د/ محمد حسنين عبده العجمى } \\
& \text { أ.د/ جـابر محمـود طلبــه الكارف } \\
& \text { أستاذ أصول التربيت } \\
& \text { أستاذ تخصص تربيت الطفل } \\
& \text { وعميد } \\
& \text { والعميد المؤسس } \\
& \text { لكليتر رياض الأطفال - جامعت المنصورة }
\end{aligned}
$$

$$
\begin{aligned}
& \text { المجلتتالعلميت لكليتتالتربيت للطفولت المبكرة ـ جامعت المنصورة } \\
& \text { المجلد السابع ـ العدد الثانى } \\
& \text { أكتوبر r.r. }
\end{aligned}
$$

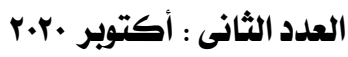




\section{متطلبات تحقيق جودة المناخ التنظيمي بمؤسسات}

\section{رياض الأطفال}

\section{د/أميرة أحمد محمد حسن رضوان}

ملخص البحث

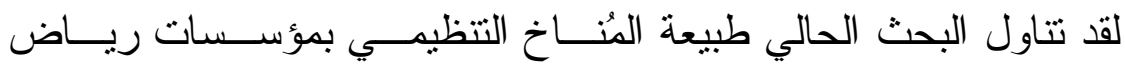

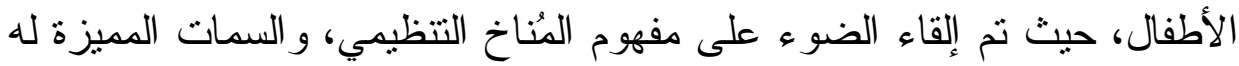

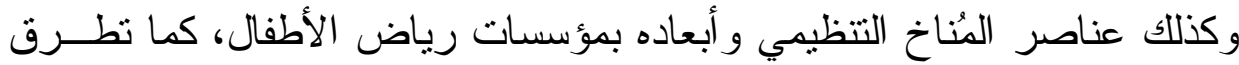

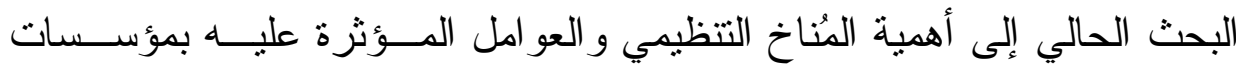

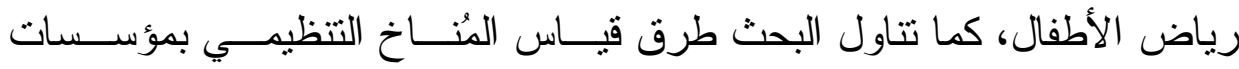

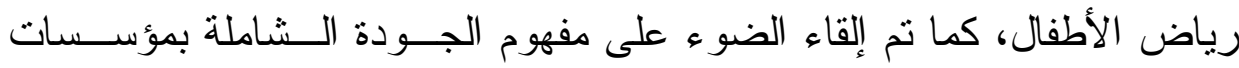

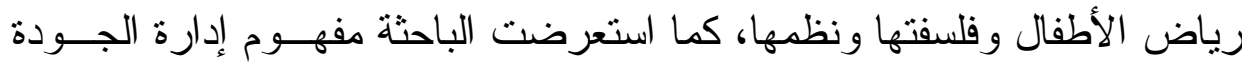

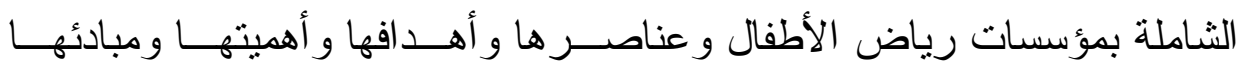

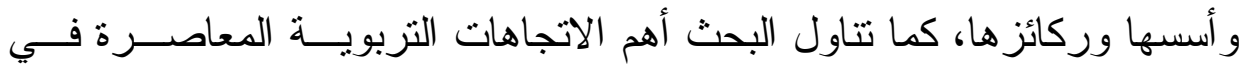

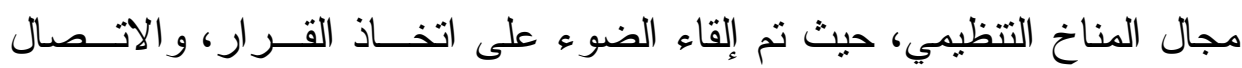

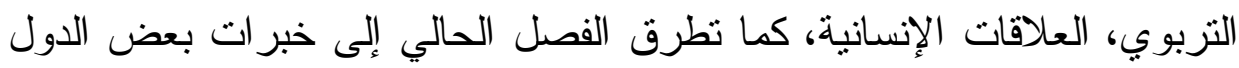
العربية و الأجنبية (المملكة العربية السعودية- الأردن - ألمانيا- اليابان - ماليزيا)

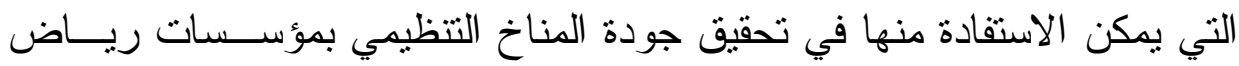

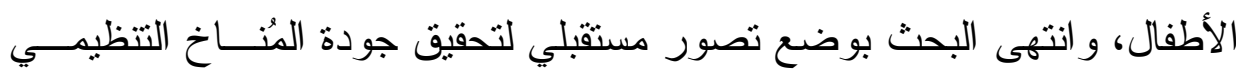

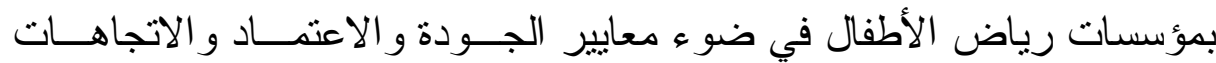

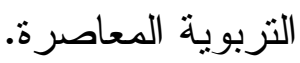
الكلمات المفتاحية: المُناخ التتظيمي - مؤسسات رياض الأطفال - الجودة * مدرس مساعد بقسم أصول تربيت الطفل ـ كليت التربيت للطفولت المبكرة. جامعت المنصورة 


\section{متطلبات تحقيق جودة المناخ التنظيمي بمؤسسات}

\section{رياض الأطفال}

\section{دأميرة أحمد محمد حسن رضوان}

\section{مقدمة}

لكل بناء أساساً يرتكز عليه، وقوة البناء تعتمد على صلابة أساسه، ويعتبر

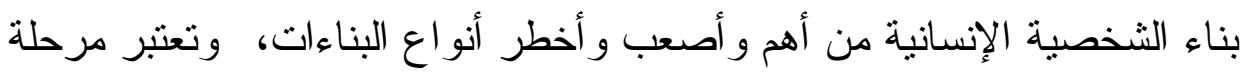

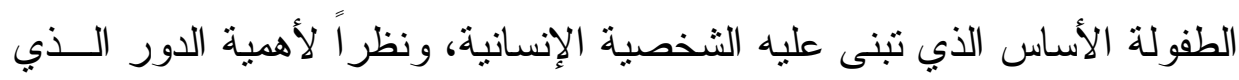

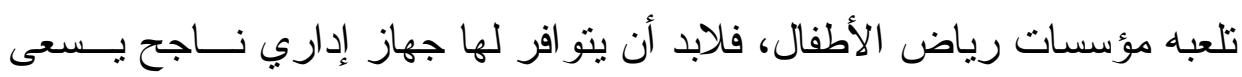

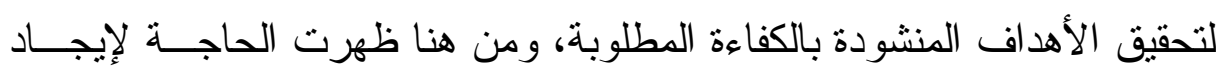

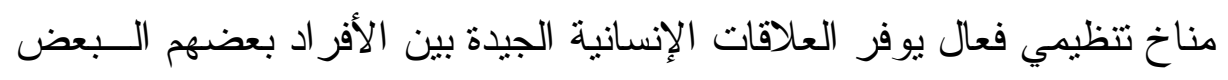
مما يسهم في تحقيق الأهداف المرجوة.

ولقد أصبح الاهتمام بالجودة ظاهرةٌ عالمية، وذلك بعد أن أصبحت الجودة

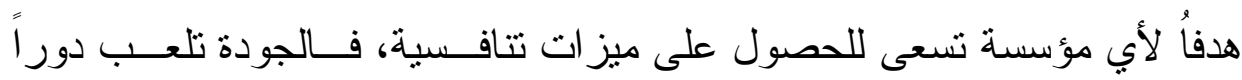

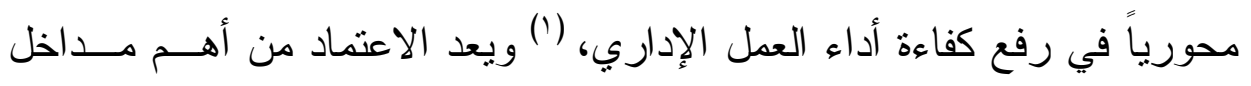

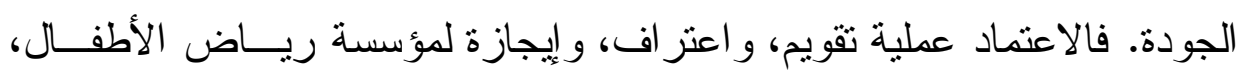

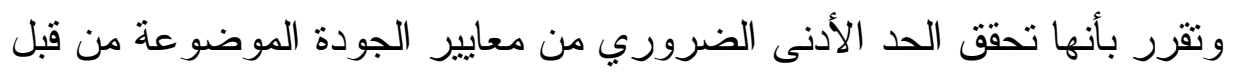

* مدرس مساعد بقسم أصول تربيت الطفل ـ كليت التربيت للطفولت المبكرة. جامعت المنصورة

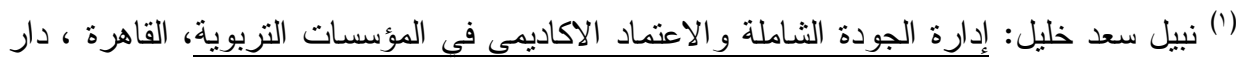

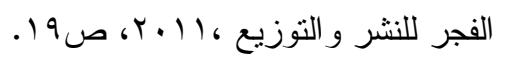


الهيئة. (') وحتى تتمكن مؤسسات رياض الأطفال من مو اكبة متغيــر ات العــصر

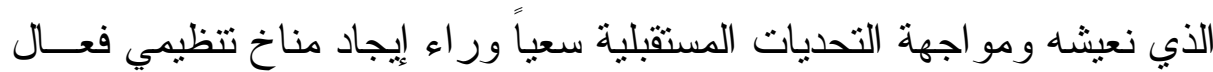
يسهم في زيادة فعالية المؤسسات، فهذا يحتاج الأستفادة من الاتجاهات التربويـــة المعاصرة، ومن ثم تزي الباحثة ضرورة القيام بدر اسة منطلبات تحقيــق جــودة المُناخ التنظيمي بمؤسسات رياض الأطفال . الدر اسة الاستطلاعية

قامت الباحثة بعمل در اسة استطلاعية للتعرف على و اقع المُناخ التتظيمي بمؤسسات رياض الأطفال، وقد توصلت الباحثة من خلال الدر اسة الاستطلاعية لمجمو عة من المؤشر ات حول و اقع المُناخ التظظيمي القائم بمؤســسات ريــاض الأطفال تمنلت فيما يلي: بالنسبة للمعوقات المادية للمناخ التنظيمي: - معظم مؤسسات رياض الأطفال ملحقة بمدارس تم إنشاؤها عن طريق هيئة الأبنية التعليمية ولكنها تفقر إلى بعض التجهيز ات و الأجهزة الحديثة.

$$
\text { - و وجود عجز في بعض الأثاث بالروضة. }
$$
- ضعف ملائمة تجهيز ات القاعات للأطفال ذوي الاحتياجات الخاصة.

$\left.{ }^{1}\right)$ J.ClasienDe Schipper \& Louis W.CTavecchio : Goodness-of-fit in Center day Care; Relations of Temperament, Stability, and Quality of care with the Child's Adjustment, Center for Child and Family Studies, Leiden University, 2004. PP.257-272.

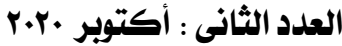


- ميز انية رياض الأطفال تدخل ضمن ميز انية المدرسة و لا يوجـــ منــدوب

$$
\text { مالي لمؤسسات رياض الأطفال (سكرنير). }
$$

- معظم مؤسسات رياض الأطفال ليس لها فناء مخصص.

بالنسبة للمعوقات الإدارية للمناخ التنظيمي:

$$
\text { - معظم القاعات بها معلمة واحدة. }
$$

- في مدارس التعليم الابتدائي يتولى مدير المدرسة الإثر اف على مؤسسات

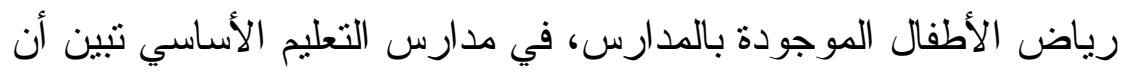

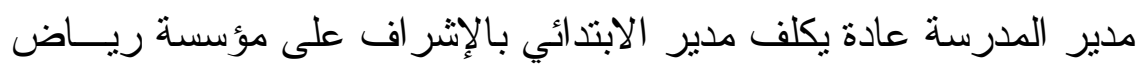

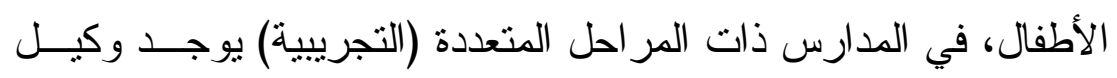
يتولى الإثر اف على مؤسسة رياض الأطفال. بالنسبة للمعوقات البشرية للمناخ التنظيمي:

$$
\text { - وجود عجز في عدد معلمات رياض الأطفال. }
$$

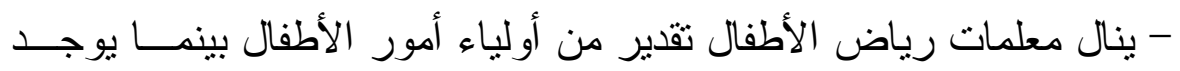

$$
\text { نظرة متدنية لهم من باقي أفر اد المجتمع. }
$$

\section{بالنسبة للمعوقات التكامل مع الأسرة للمناخ التنظيمي:}

- نادراً ما تقوم بعض الروضات بعمل رحلات خارجية للأطفال.

- ضعف المشاركة المجتمعية لأولياء أمور الأطفال بالروضة.

- لا يشارك أولياء أمور الأطفال في أنشطة الروضة. 


\section{بالنسبة للمعوقات التكامل مع البيئة الخارجية:}

- ضعف وجود تبادل زيار ات بين الروضات الحكومية بعضها الــبعض،و لا

بينها وبين الروضات الخاصة وذلك لضعف الميز انية.

- تو اجد بعض الأسو اق بالقرب من مؤسسات رياض الأطفال مدــــــــبـب

الضوضاء للأطفال.

در اسات سابقة

المحور الأول: دراسات سابقة تتعلق بـالمنّاخ التنظيمي وعلاقته بـالجودة

\section{و الاعتماد}

(1)

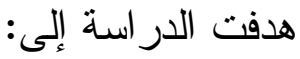

التعرف على العلاقة بين المُناخ التتظيمي وبيئة العمل للمعلمين بمرحلــة

ما قبل المدرسة، وجودة الفصول الدر اسية .

وقد تتاولت الدر اسة أهمية جودة الفصول الدر اسية للأطفال، وخاصة بين

الأطفال من ذوي الاخل المنخفض.

وقد استخدمت الدر اسة المنهج الوصفي، وتمنتل ع عينة الدر اسة فـي

مركز من مر اكز خدمة الأسر ذات الدخل المنخفض في شــــال شــرق مدينــة كبيرة.

(') Sarah E. Dennis: " Reexamining Quality in Early Childhood Education: Exploring the Relationship Between the Organizational Climate and the Classroom", Journal of Research in Childhood Education, Vol.( 27), 2013.

العدد الثانى : أكتوبر •r.r

or

الإجلد السابع 


\section{من أهم نتائج الار اسةة: - 20 - من}

1-توجد علاقة ذات دلالة احصائية بين المُناخ التنظيمي العام وجودة الفصول الدراسية بحيث الفصول الدراسية الموجودة في مر اكز تكون أكثر ايجابيــة من حيث المُناخ التنظيمي العام (على سبيل المثال، الزمالة، و النمو المهني،

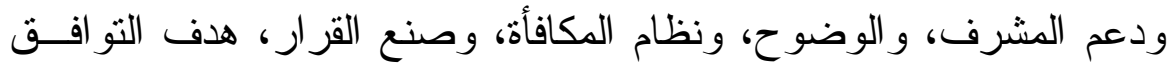
و التوجه المهمة، وتحديد البدني، و الابتكار)، و المُناخ التنظيمي (على ســيل التيل

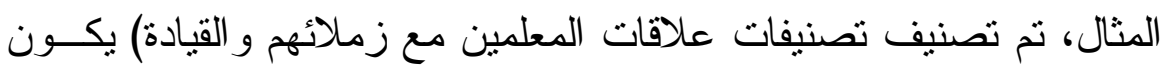
أفضل مع جودة الفصول الدر اسية. ץ-توجد علاقة وثيقة بين المُناخ النتظيمي وجودة الفصول الدر اسية تمثلت في العلاقة بين المعلمين من ذوي الخبرة الأكبر و التعليم الأقل.

\section{('). r. r. r. أميرة عبد الحمبي أحمد شهية

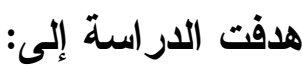

صياغة تصور مقتر ح يقلل من المعوقات التي تحول دون تحقيق الفعاليــة التعليمية بمؤسسات رياض الأطفال وقد تتاولت الدراسة الإطار الدفاهيمى للجودة التعليمية بمؤسسات ريــاض

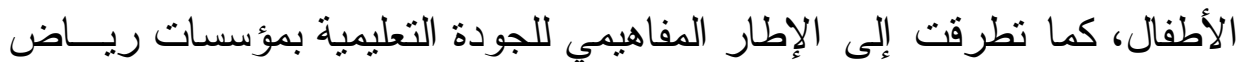

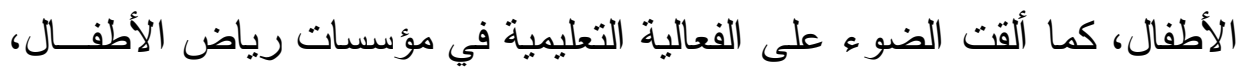

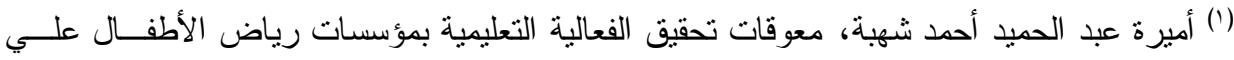
ضوء وثثقة معايير الجودة (در اسة ميدانية بمحافظة الدقهلية)، رسالة ماجستير غير منشورة، كلية

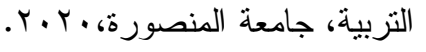


و انتهت بصياغة تصور مقترح يفعل من الفعالية التعليمية في مؤسسات ريــاض

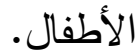

وقد استخدمت الدر اسة المنهج الوصفي، وتمنلـــت أدوات الدراســة فـي

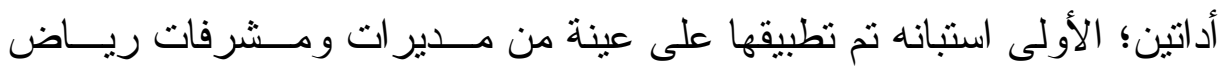

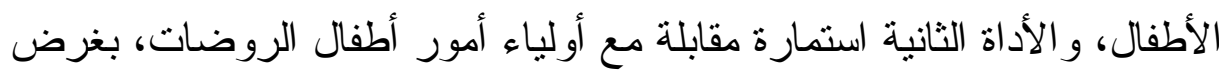

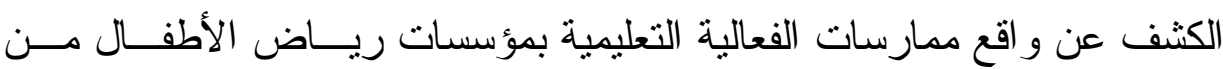

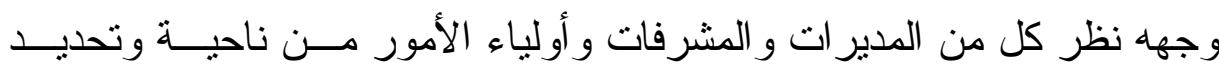

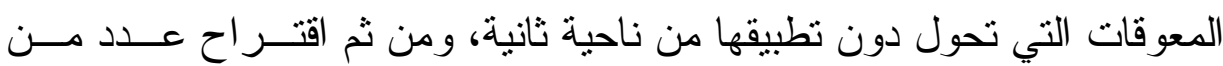
المتطلبات التي تلزم التفعيلها من ناحية ثالثة.

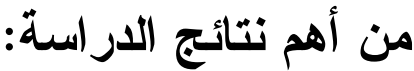

1- يمكن تطبيق الجودة من خلال عدة آليــات منهـــا إدخــال التكنولوجيــــا

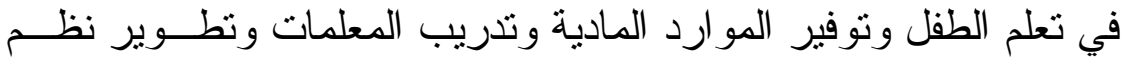

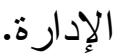

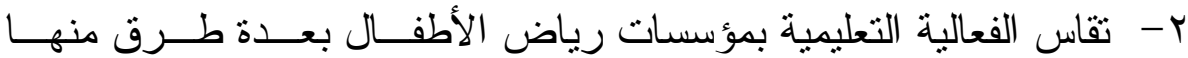

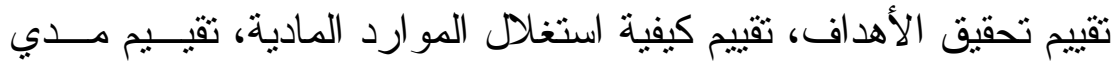

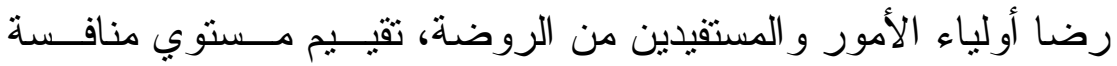

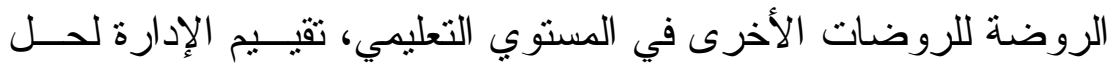

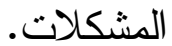
r- للمعلمة دور هام ومؤثر في الارتقاء بمستوي التعلم بالروضة. 
تعقبب على الار اسات السابقة التي اهتمت بالمُناخ التنظيمي لمؤسسات رياض الأطفال وعلاقته بالجودة والاعتماد

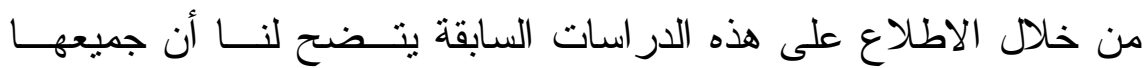
اهتمت بالمُناخ التنظيمي وعلاقته بالجودة و الاعتماد في المؤسسات المختلفة، فقد الأد

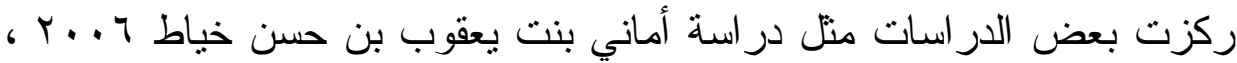

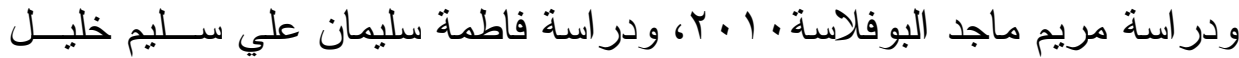

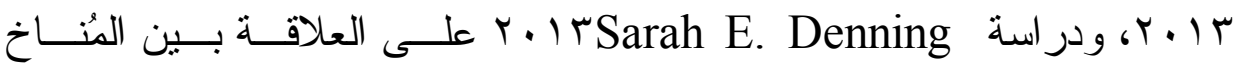
التنظيمي و الجودة و الاعتماد بمؤسسات رياض الأطفال.

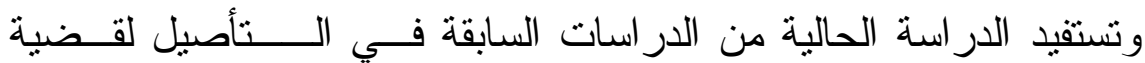

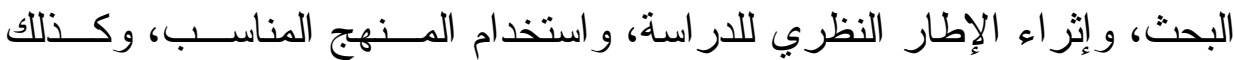

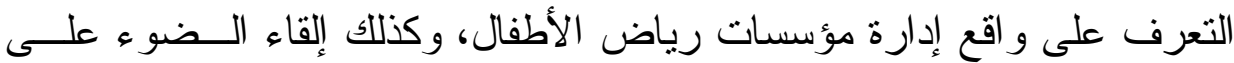
أهمية المُناخ التتظيمي و أهمية تطويره وكنية وكنلك العو امل المؤثرة فيه.

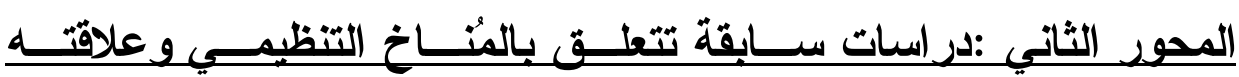
بالاتجاهات التريوية المعاصرة

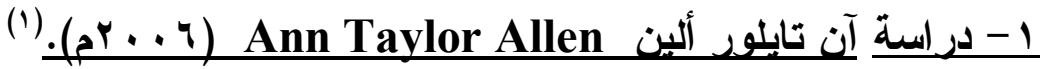

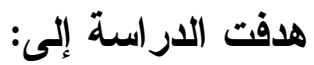

عمل مقارنة بين ألمانيا و الو لايات المتحدة الأمريكية من عام •ـ1 ا إلـى $.0191 \leq$

${ }^{(1)}$ Ann Taylor Allen : " The Kindergarten in Germany and the United States, 1840-1914: A Comparative Perspective", History of Education, Vol. (35), Iss.(2), 2006.

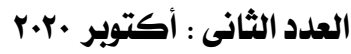


وقد تتاولت الدراسة المقارنة بين ألمانيا و الو لايات المتحدة الأمريكية فـي ثلاث جو انب: العلاقة بين الكنيسة و الدولة، وتطور الحركات النسائية، والــسياق السياسي الذي تطور فيه أنظمة المدارس العامة. وقد استخدمت الدر اسة المنهج المقارن. من أهم نتائج الار اسة: 1- حققت رياض الأطفال في الولايات المتحدة الأمريكية نجاحا أكبر بكثيــر

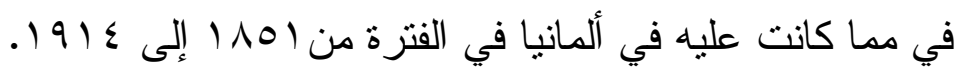

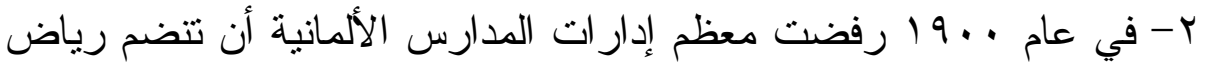

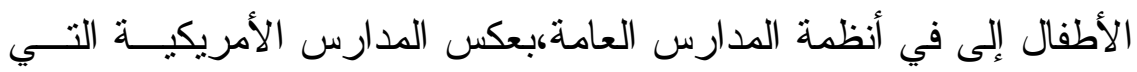
تضنت رياض أطفال داخل المدارس العامة. r- أكد فروبل على دور النساء في تربية الأطفال لأنهن مربييات موهوبـات

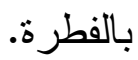

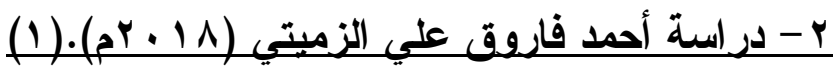

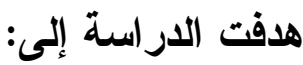

تقديم تصور مقترح لنظوير مؤسسات رياض الأطفال بجمهوريــة مـصر

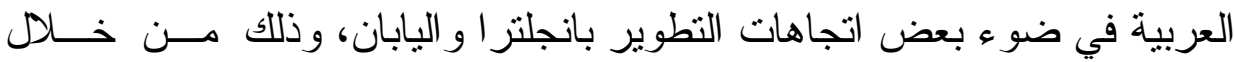

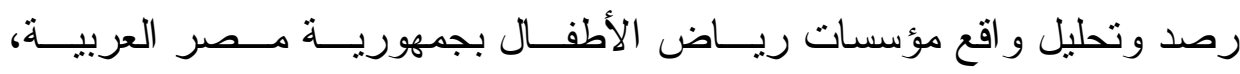

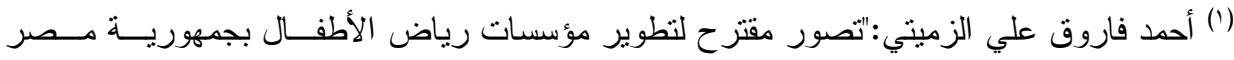

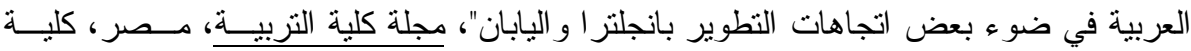

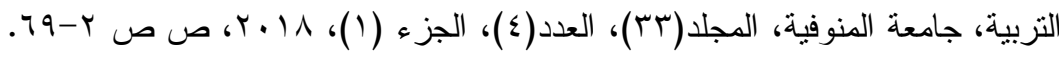

العدد الثانى : أكتوبر •r.r or 
و واستعر اض بعض اتجاهات التطوير لمؤسـسـات ريــاض الأطفــال بــانجلترا و اليابان، للاستفادة منها في صياغة التصور المقترح.

وقد تتاولت الدر اسة و اقع مؤسسات رياض الأطفــال بجمهوريــة مــصر

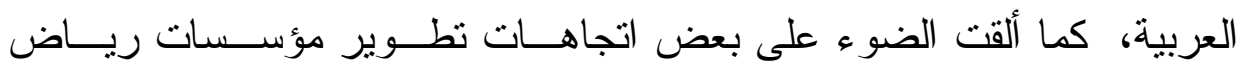

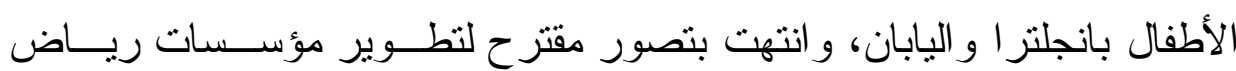

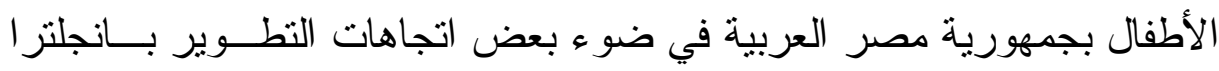

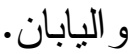

وقد استخدمت الدراسة المنهج الوصفي، وقد اقتـــرت الدراســة علــى

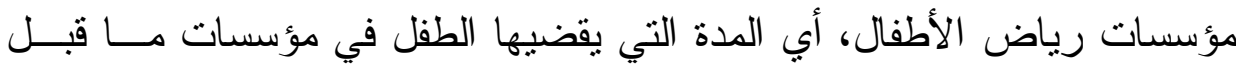

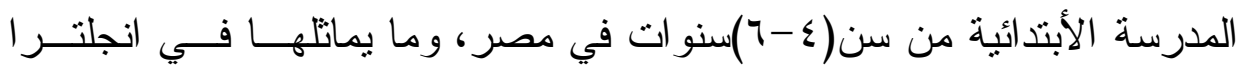

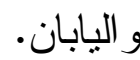
من أهم نتائج الار اسة: - من التوصل إلى تصور مقترح لتطوير مؤسسات رياض الأطفال بجمهوريـــة مصر العربية في ضوء بعض اتجاهات التطوير بانجلتر او اليابان. تعقبب على الدراسات السابقة التي اهتمت بالمُناخ التنظيمي لمؤسسات رياض الأطفال وعلاقته بالاتجاهات التربوية المعاصرة لقد تبين من خلال عرض الدراسات السابقة المتعلقة بالمحور الثاني أنهـــا

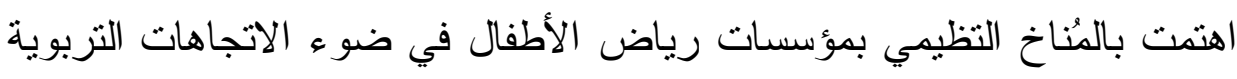

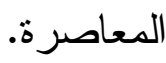


وتستفيد الدراسة الحالية من هذه الدراسات السابقة في الإطار النظري من

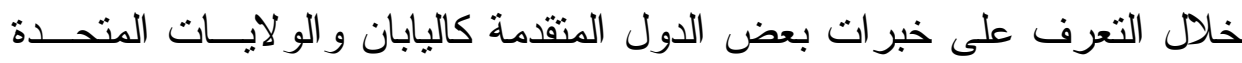

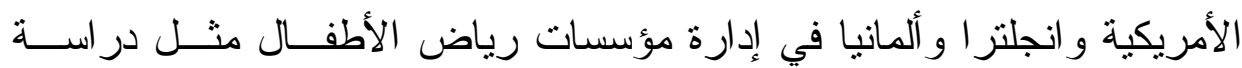

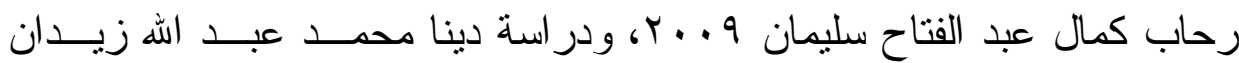

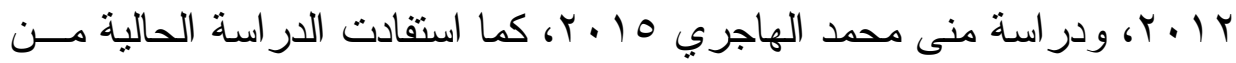

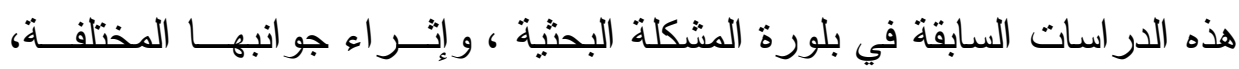

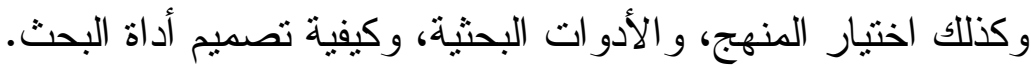

المحور الثالث :دراسات سابقة تتعلق بالمُناخ التنظيــي لمؤسـسـات ريسـاض الأطفال وعلاقته بكل من الجودة والاعتماد والاتجاهات التريوية المعاصرة نظر اً لندرة الدراسات السابقة في مجال المُناخ التتظيمي و علاقته بــالجودة

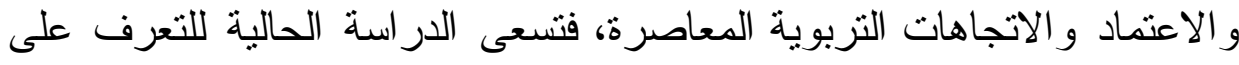

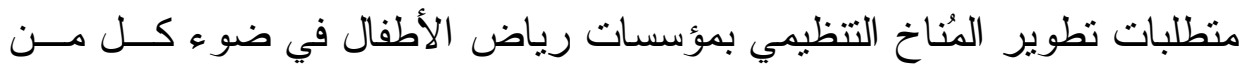
معايير الجودة والاعتماد و الاتجاهات التربوية المعاصرة.

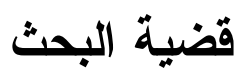

تتحدد قضية البحث الحالي فيما تحمله العبارة التالية من أفكار ومــضامين

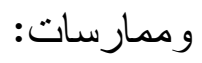

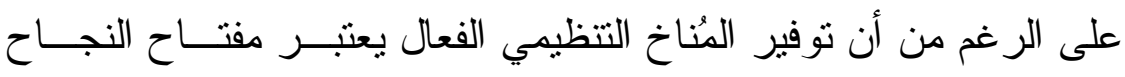

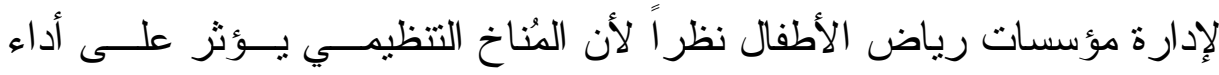

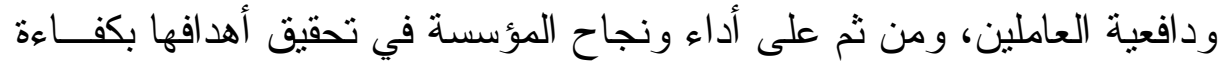

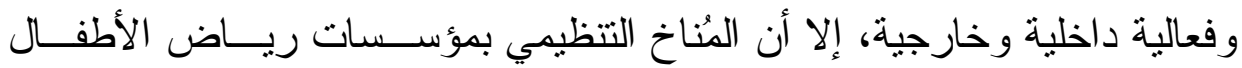

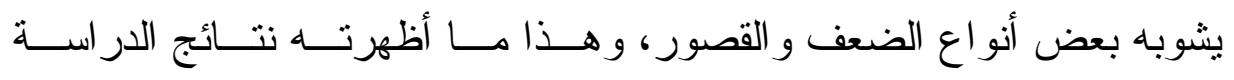


الاستطلاعية التي اجرتها الباحثة، الأمر الذي يتطلب البحــث و الدراســة عـنـ

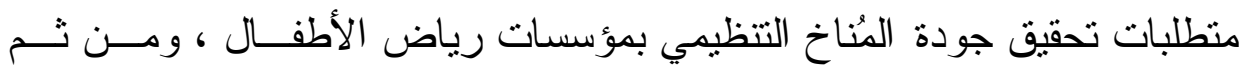
تطرح قضية البحث الحالي في السؤال الرئيسي الثالي:

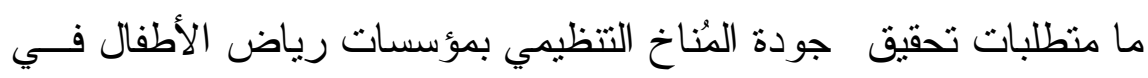

ضوء الاتجاهات التربوية المعاصرة ؟ التطان

ويطرح السؤ ال الرئيسي مجموعة التساؤلات الفرعية التالية:

1- ما الإطار المفاهيمي للمُناخ التنظيمي بمؤسسات رياض الأطفال؟

r- ما أهم معايير الهيئة القومية لضمان جودة التعليم و الاعتمــاد التــي يمكـن

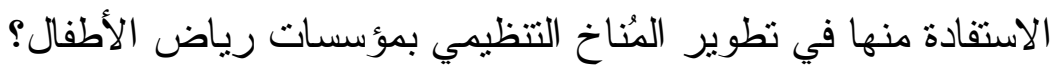

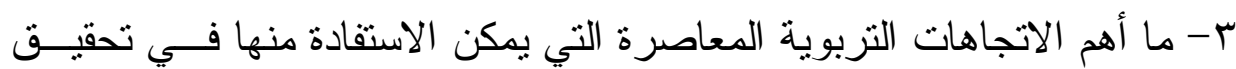

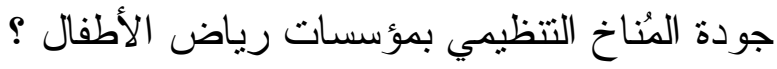

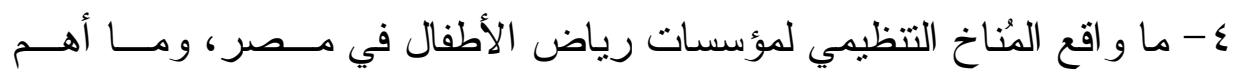

المعوقات التي تحول دون نجاحه في تحقيق الأهداف المنشودة له؟

ه- كيف بمكن الاستفادة من الاتجاهات التربوية المعاصرة في تحقيـق جـودة

المُناخ التنظيمي بمؤسسات رياض الأطفال؟ من الاهن

أهداف البحث

يهدف البحث الحالي إلى محاولة تحقيق الأهداف التالية :

1-عرض وتحليل الإطار الدفاهيمي للمُنّاخ التنظيمسي بمؤسـسـات ريــاض

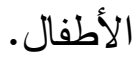


r- التعرف على أهم معايير الهيئة القومية لضمان جودة التعلـــم و الاعتمــاد

التي يمكن الاستفادة منها في تحقيق جودة المُناخ التظظيمــي بمؤسـسـات

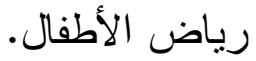

ب- تحديد أوجه الاستفادة من الاتجاهات التربوية المعاصرة في تحقيق جــودة المُناخ التظيمي بمؤسسات رياض الأطفال .

ع - تحديد أهم ملامح الو اقع الر اهن للمنــاخ التظظيهـي لمؤســسات ريـــاض

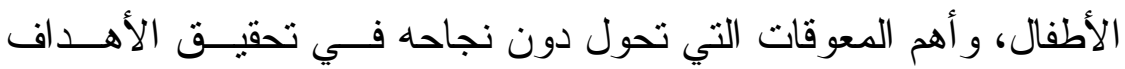

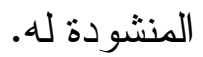

0- طر ح تصور مستقبلي لمنطلبات تحقيق جودة المُناخ التتظيمي بمؤسـسـات

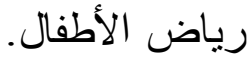

\section{أهمبة البحث}

1- تكمن أهمية البحث الحالي في أهمية القضية التى يتتاولها.

r- يعنبر البحث الحالي بمثابة دعوة جادة لأهمية تــــفير المُنــاخ التظظيـــي

$$
\text { الإنساني بمؤسسات رياض الأطفال. }
$$

ب- تَعدّد الفئات المستفيدة من البحث الحالي، ومنهم صانعو السياسة التربوية ومتخذو القرار التزبوي في مصر و القائمون علــى مؤسـسـات ريــاض الأطفال في مصر ، إضافةً إلى طفل الروضة، ومُعلّمة الروضة، و وأوليــاء الأمور ، و المجتمع المحلّي، و الروضات. 


\section{منهج البحث}

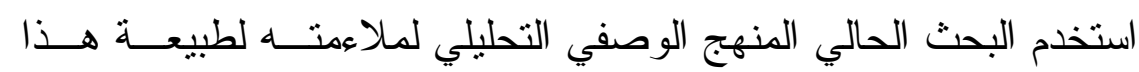

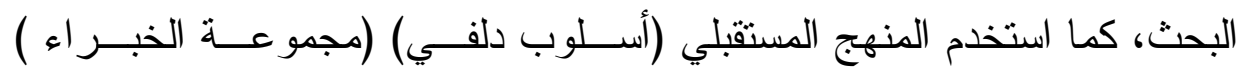
وصو لاً إلى التصوّر المستقبلي. عينة البحث

نم النطبيق على عيّنة من مديري ومعلمات مؤسـسـات ريــاض الأطفــال

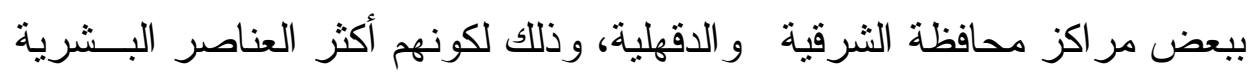

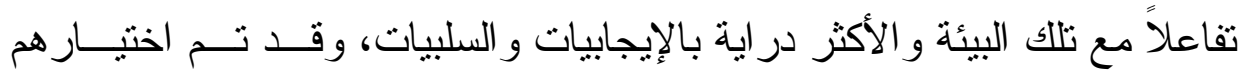

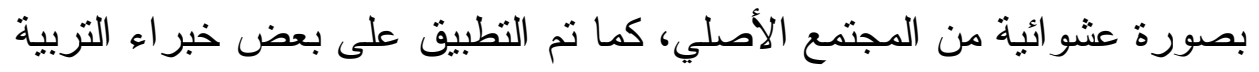

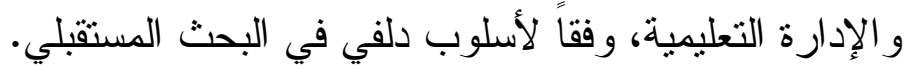

$$
\text { أدوات البحث }
$$

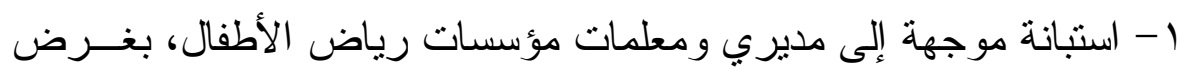

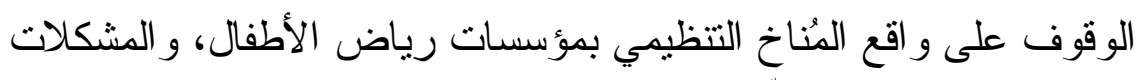
التي تو اجهه، وسبل التخلّب عليها.

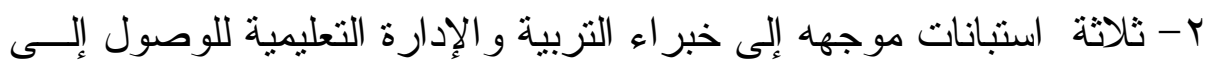

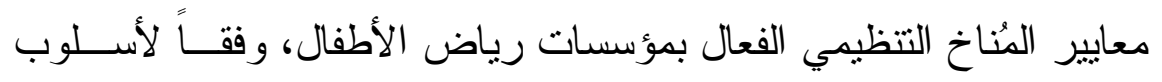

$$
\text { حدود البحث دي البحث المستقبلي. }
$$

1- الحدود الأكاديمية: ركز البحث الحالي على دراسة متطلبات تحقيق جودة

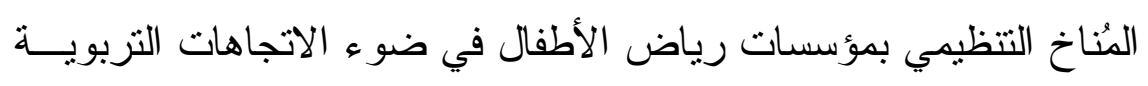

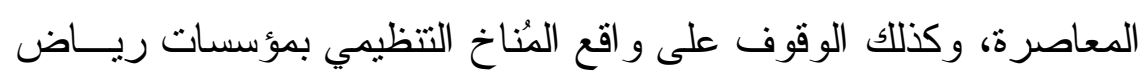
الأطفال، و المشكلات التي تو اجهه، وسبل التغلّب عليها. 
r- الحدود البشريةة: اقتصرت الدر اسة الحاليــة علــى مــديري ومعلمــات

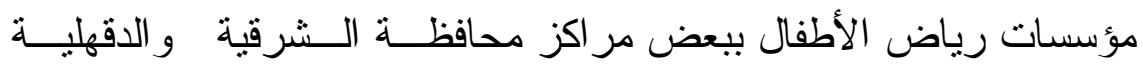

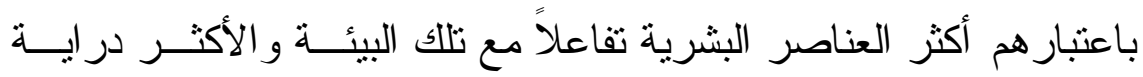

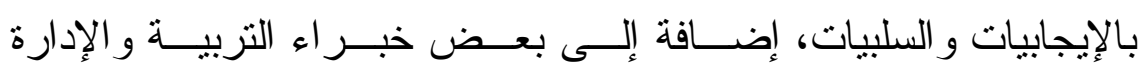

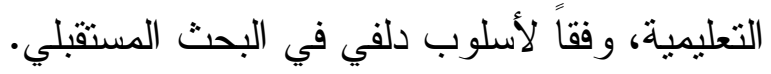

ب- الحدود الزمنية: عملت الدراسة الحالية في الإطار الزمني للبحث وهـــ

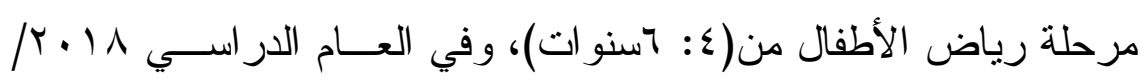

$$
\cdot r^{r} \cdot 19
$$

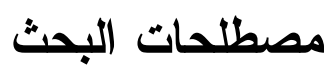

\section{The Organizational Environment}

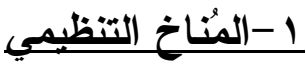

1- يعني تلك الثخصية الإدارية التي تتميز بها المؤسسة التعليمية، من حيث

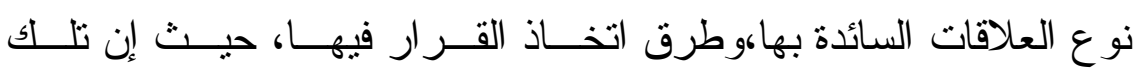
الشخصية تتمنل في مجموعة الخصائص التي تميز إحــدى المؤسـسـات التعليمية عن غيرها، و التي تؤثز في سلوك الأفر اد، وتكون نتائج عمليــة التفاعل بين المدير و العاملين معه في المؤسسة التعليمية. (') r- هو الظروف الإدارية و الاجتماعية و النفسية و الماديـــة و البيئيـــة الــــائدة داخل المؤسسة التعليمية و التـي تــؤثز فــي العلاقــات الوظيفيــة بــين

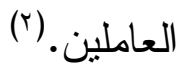

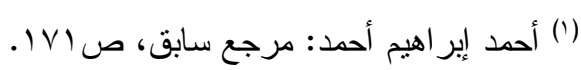

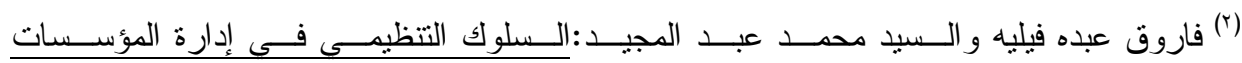

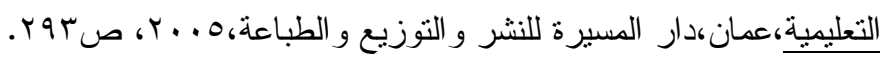

المجلد السابع


The Operational Defination of the Organizational Environment

هو الخصائص الإدارية و التزبوية و النفسية و الاجتماعية التي تتميـز بهــــا

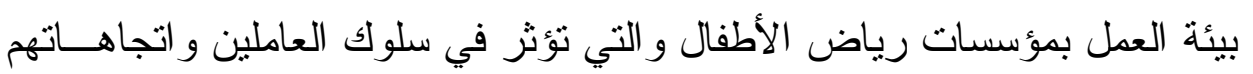
و وأدائهم.

kindergarten

r r ب بياض الأطفال

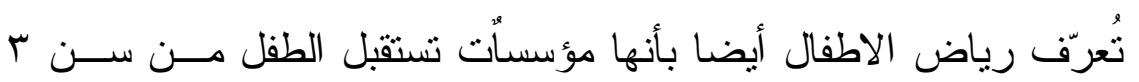

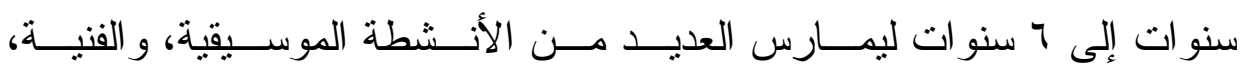

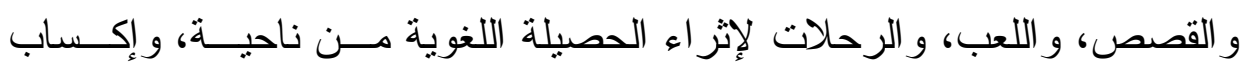

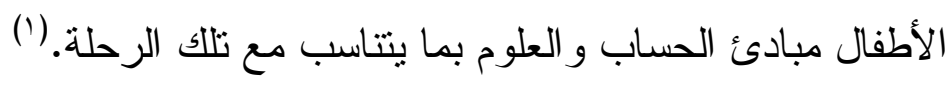
التعريف الإجر ائي لمؤسسات رياض الأطفال

The Operational Defination of Kindergarten Institutions تتبنى الباحثة تعريف جابر طلبة كتعريف إجر ائي لمؤسسات رياض الأطفال

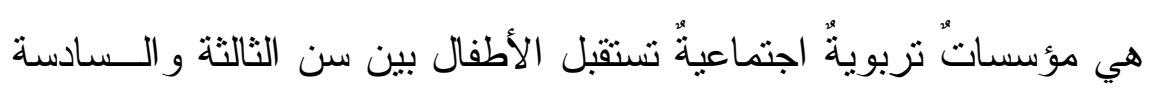

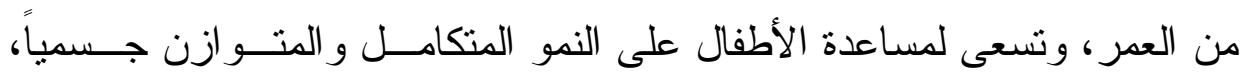

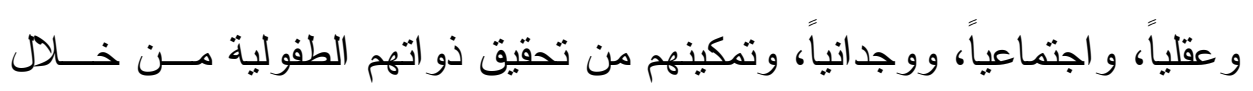

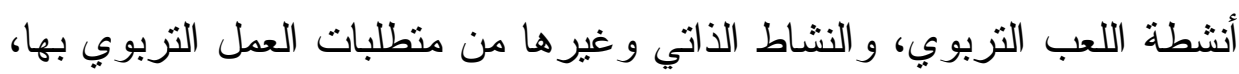

(') عبد الخالق فؤ اد محمد عبد الخالق ومحمد محمود محمدعلي: مدخل لرياض الأطفال، الدمام ،مكتبة

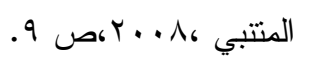

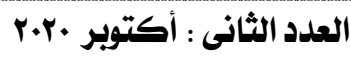

$7 \varepsilon$

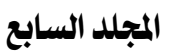


بما يلبّي احتياجات هؤلاء الأطفال، ويتو افق مع متطلبات نزبية أطفال مـــا قبـــلـ

الدر اسة في إطار ثقافة المجتمع. (')

\section{إجر اعات البحث}

تمت معالجة قضية البحث وفق الخطو ات التالية:

1 - عرض الإطار العام للبحث و الذى يتضمن: مقدمة البحــث - در اســات

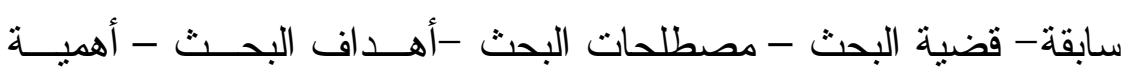

البحث - المنهج البحثي المستخدم - عيّنة البحث -أدوات البحث - حدود

$$
\text { البحث- إجر اءات البحث. }
$$

r- التتظير للمُناخ التتظيمي بمؤسسات رياض الأطفال، من خلال الاطــلاع على كافة البيانات و الأدبيات المتعلقة بموضوع البحثي.

ب- إلقاء الضوء على أهم معايير الهيءٔــة القوميــة لــضـمان جــودة التعلــيم و الاعتماد التي يمكن الاستفادة منها في تحقيق جـــودة المُّـــاخ التتظيـــي

$$
\text { بمؤسسات رياض الأطفال. }
$$

ع - عرض أهم الاتجاهات التربوية المعاصرة للاستفادة منها في تحقيق جودة

$$
\text { المُناخ التنظيمي بمؤسسات رياض الأطفال. }
$$

0- قامت الباحثة بتصميم استبانة موجهة إلى عينّة مــن مسـديري ومعلمـات

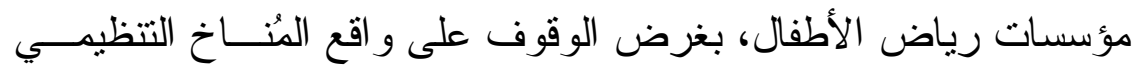

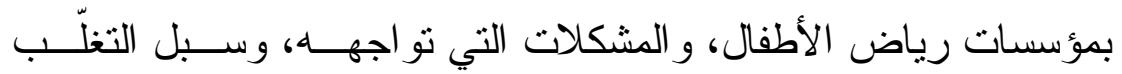

(') جابر محمود طلبة :الانتقال الفعال إلى رياض الأطفال، (سلسلة الطفل أصيل-0)، المنصورة،مكتبة

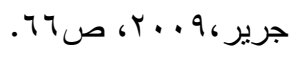

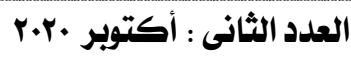

70

المجلد السابع 
عليها، كما قامت الباحثة بتصميم ثناثة استبانات موجهــه إلــى خبــر اء

التزبية و الإدارة التعليمية للوصول إلى معايير المُناخ التنظيمــي الفحــال بمؤسسات رياض الأطفال وفقاً لأسلوب دلفي في البحث المستقبلي.

7- وبعد جمع المعلومات، و البيانات، وتفسير ها قامت الباحثة بوضع تـصور

مستقبلي لمنطلبات تحقيق جودة المُنـــاخ التنظيمـــي بمؤســسـات ريـــاض

الأطفال في ضوء الاتجاهات التربوية المعاصرة .

\section{أولاً:الإطار النظري للبحث}

تم تقسيم الإطار النظرى للبحث إلى ثلاث محاور وهـــى المحسـور الأول:

ويشمل المُناخ التتظيمي بمؤسسات رياض الأطفال، و المحور الثــانى : طبيعــة

الجودة بمؤسسات رياض الأطفال ، و المحور الثالث: يشمل المفاهيم و المهــار ات

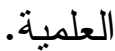

(أ) المحور الأول: المُناخ التنظيمي بمؤسسات رياض الأطفال 1 - مفهوم المُناخ التنظيمي بمؤسسات رياض الأطفال

انطلقت جذور مفهوم المُناخ التتظيمي من مدرسة العلاقات الإنسانية التي

أكدت علي تأثير العو امل الاجتماعية والتظيمية و النفسية في إنتاجية الفرد، وفي بداية الستينات بدأ الاهتمام بدر اسة ارتباطات هذا الموضـــوع ضــــن الــسلوك التتظيمي ونظرية التتظيم. (')

(') عاطف عوض:"تحسين المُناخ التظظيمي في الجامعات مدخل لتطوير أداء الموظفين"، مجلة الجنان،

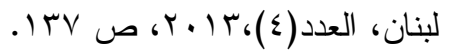

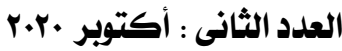

77

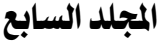


ومن ثم يمكن تعريف المُناخ التتظيمي بمؤسسات رياض الأطفــال بأنـــهـ مجموعة من الخصائص التي تميز بيئة العمل الداخلية بمؤسسة رياض الأطفال، وتتمتع بقدرتها على التأثير في دو افع العاملين، وتتعكس على مـستوى أدائهـ

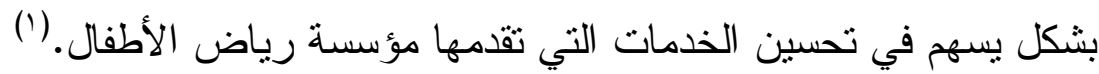
و عليه يمكن تعريف المُناخ التنظيمي بالبحث الـــر اهن بأنـــهـ الخــصائص

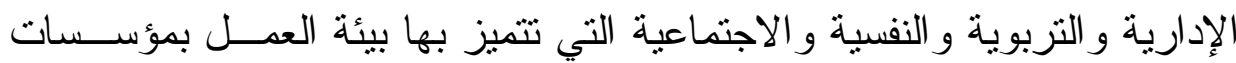
رياض الأطفال و التي تؤثر في سلوك العاملين و اتجاهاتهم و أدائهم. r-السمات المميزة للمُناخ التنظيمي بمؤسسات رياض الأطفال يعبر المُناخ النتظيمي عن كافة الظروف والعناصر التي تحيط بالعـاملين

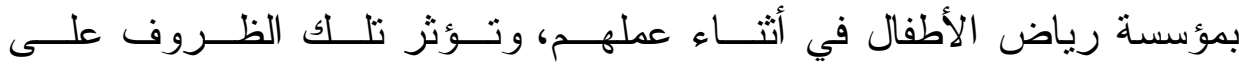
نفسية العاملين وسلوكهم و اتجاهاتهم نحو عملهم ونحو مؤسسة رياض الأطفــال

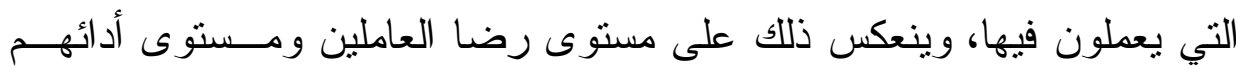

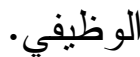
• يعد المُناخ التتظيمي سمة ثابتة نسبياًت تميز أحد المؤسسات التربوية عـن غبر ها. معكس المُناخ التنظيمي القيم و المو اقف الـــائدة فـــي ثقافــة المؤسـسـة، ويتثكل المُناخ التنظيمي من تفاعل العاملين.

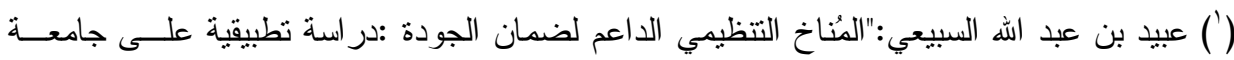

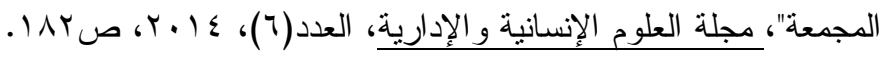

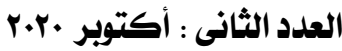


يعبر المُناخ التتظيمي عن التصور ات الجماعية للعاملين عن مؤسـساتهم

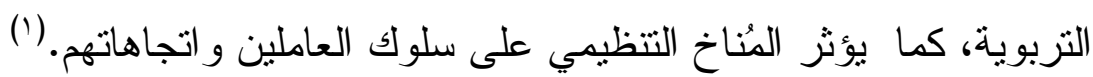

r-أهية المُناخ التنظيمي بمؤسسات رياض الأطفال

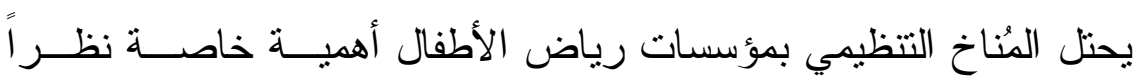

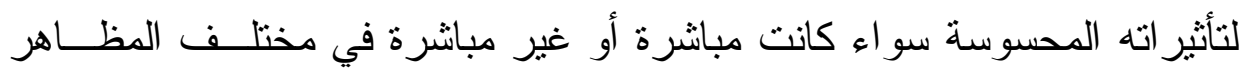
و السلوكيات الإدارية و المنصلة بالعاملين داخل مؤسسات رياض الأطفال وكذلك

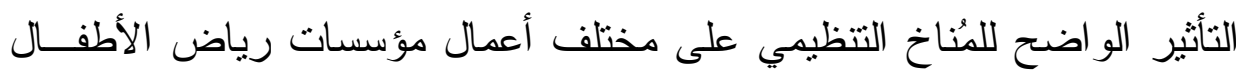

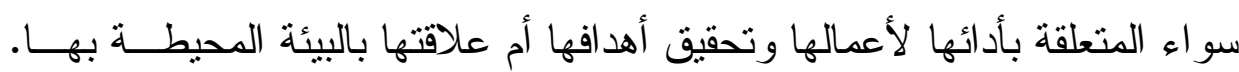

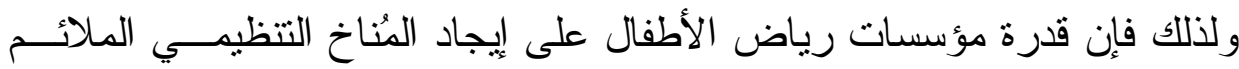
ينعكس على درجة نجاحها ووصولها إلى غاياتها المنشودة. (ب) المحور الثاني: طبيعة الجودة بمؤسسات رياض الأطفال 1 - مفهوم الجودة بمؤسسات رياض الأطفال

يمكن تعريف الجودة بمؤسسات رياض الأطفـــال بأنهـــا عمليــة نوثيــنق

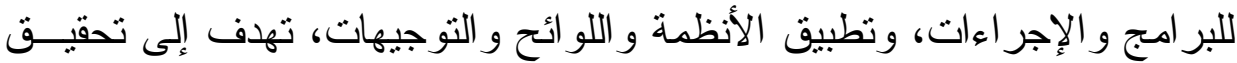

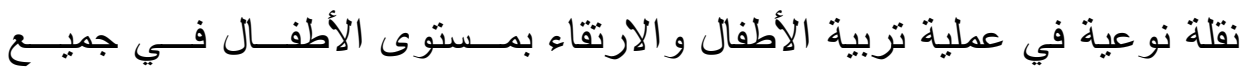

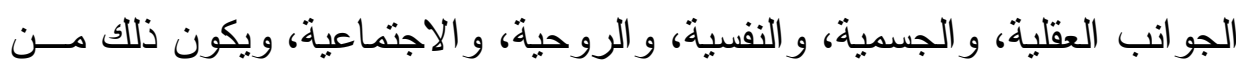

$\left.{ }^{1}\right)$ Edric L.Spruill: A Correlation Analysis Relating Organizational Climate to Employee Performance : A Case Study (PHD),University of Phoenix, 2008, PP.2-3. 
خلال إتقان الأعمال وحسن إدارتها(')، فالجودة في مؤسسات ريــاض الأطفــال تعني الجودة الثاملة في منظومة العملية التعليمية، أي تشمل جــودة المــدخلات و العمليات و المخرجات، و التغذية الر اجعة، في إطار البيئة، بهدف تحقيــق نقلــة نوعية في تو افر جودة التعليم و الاعتز اف به في مؤسسات رياض الأطفال، وذلك لأهمية وخطورة مرحلة الطفولة وما تتركه من آثار في حياة الفرد المستقبلية.(؟) r - أهداف الجودة الشاملة بمؤسسات رياض الأطفال تسعى الجودة الثشاملة بمؤسسات رياض الأطفال لتحقيق مجموعــة مسـن الأهداف منها: ضمان التحسين الثامل و المستمر لكافة مستويات مؤسسة رياض الأطفال، وزيادة إنتاجية جميع عناصر مؤسسة رياض الأطفال، وزيادة القـدرة

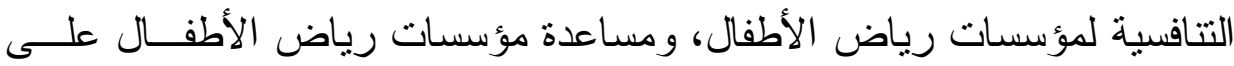
النمو و الاستمر ار، تحقيق الرضـا لدى العمــلاء بمؤســسات ريــاض الأطفــال، وتشكيل ثقافة تتظيمية تعمل على رفع كفاءة الأداء.(r)

(') رضا مسعد السعيد وأحمد ماهر عبد الحميد الباز : معايير الجودة الثـاملة في ريــاض الأطفــال،

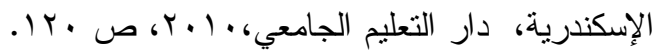

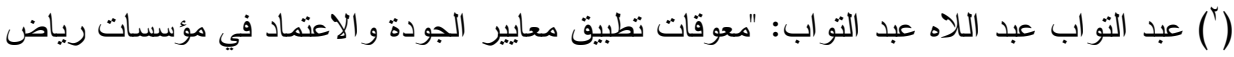

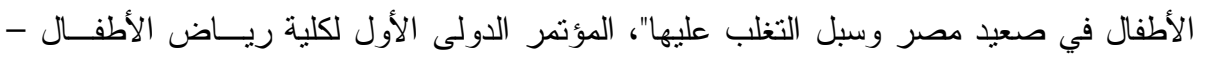

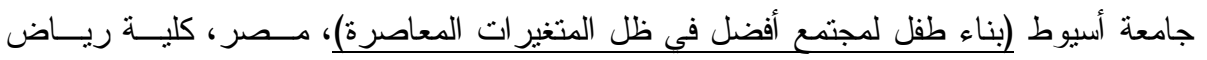

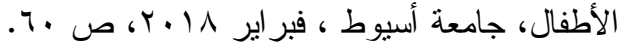

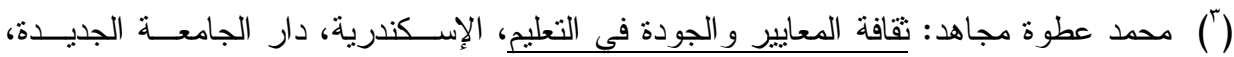

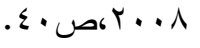


r-الأهمية و الضرورة العصرية للجودة الشاملة بمؤسسات رياض الأطفال تُعتبر الجودة الثاملة طريقةَ تفكيرٍ جديــدة لمؤسـسـات ريــاض الطفــال و أسلوباً لإدارة الموارد، يقوم على مشاركة الجميع في التخطيط و التتفيذ؛ ســياً ور اء كسب رضنا العملاء في الحاضر و المستقبل معتمدة علــى تعـاون جميـع الأفر اد داخل مؤسسات رياض الأطفال، إضافةً إلى التز ام الإدارة العليا بــالتغيير

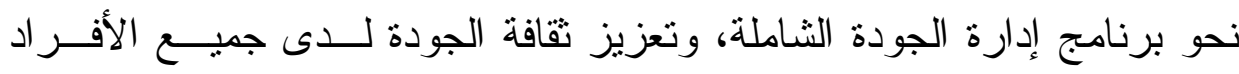
بمؤسسات رياض الأطفال، و إيجاد مقاييس موضوعية تُكّن الأفر اد من تحقبــق الأداء المنسجم مع هذه المعايير •

(ج) المحور الثالث: الاتجاهات التربوية المعاصرة في مجال المُناخ التنظيــي بمؤسسات رياض الأطفال

تتعدد الاتجاهات التزبوية المعاصرة في إدارة رياض الأطفال حيث يتبـع

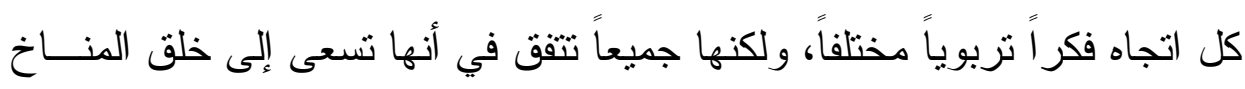
التتظيمي الصحي الذي يشعر فيه جميع العاملين بالإنسانية مما يــنعكس إيجابيــاً

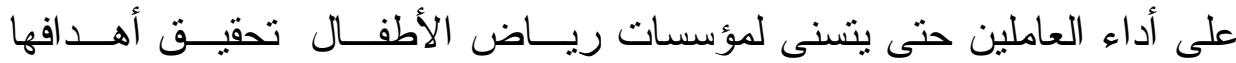
المنشودة بكفاءة وفعالية - اتخاذ القزار بمؤسسات رياض الأطفال يعد اتخاذ القرار مــن أهــم عناصــر العمليــة الإداريـــة بمؤسـسـات

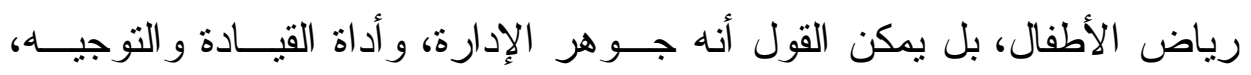
حيث أن أب تطوير لإدارة مؤسسات رياض الأطفال يعتمد على أفضل القرارات 
التي تصدر بشأنها، ولهذا فإن اتخاذ القرار تعتبر جـوهر وظيفــة مــن يعهـل

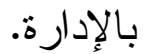

ويهدف اتخاذ القرار بمؤسسات رياض الأطفال إلى المساعدة على تحقيق

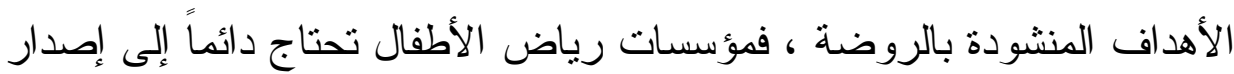

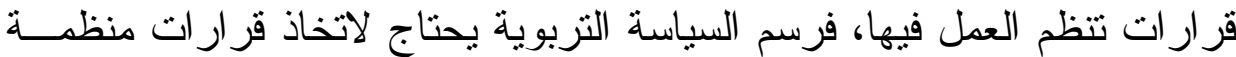

التتفيذها ومتابعتها وتحديد مسئوليات القائمين عليها.(') r - الاتصال التربوي بمؤسسات رياض الأطفال

وتكمن أهمية الاتصـال التربوي في أنه يسعى إلى تحقيـق الاتـي: الأداء

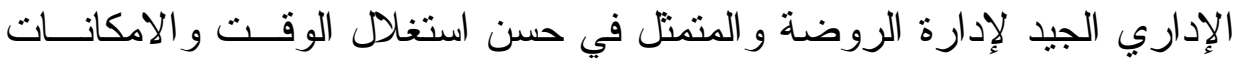
البشرية و المادية لتحقيق أهداف العملية التربوية، و الأداء التربوي الجيد و الـــي يساعد الروضة على تتمية شخصية الأطفال تتميــة شــاملة ومتكاملـــة، و الأداء

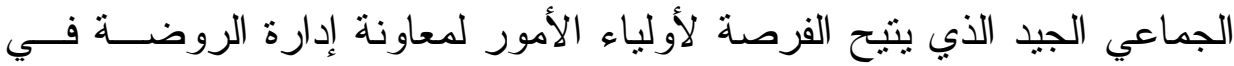
تحقيق أهداف العطلية النربوية(ك) r- العلاقات الإسانية بمؤسسات رياض الأطفال وللعلاقات الإنسانية أثز فعال على إيجاد بيئة تربوية خالية من الـضنغوط و الاضطر ابات و القلق و التوتر، فهي بلا شك تسهم في تلاحم العساملين وســيادة

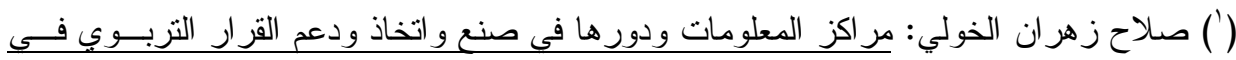

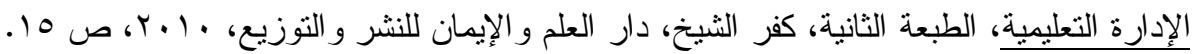

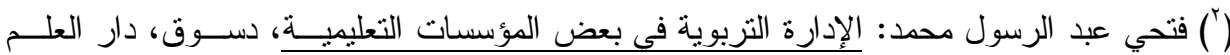

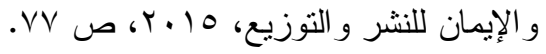


التعاون بينهم، وتساعد على بروز العمل الفريقي القائم علــى الــود و الرضـــا، و إيجاد روح التتافس الثريف، إضـافة إلى روح الابتكــار و الإبـــاع و التجديــد، وكلها أمور تسهم في غياب الثقاق و النفاق وسوء الأقوال و الثائعات، و الحد من الغياب و التأخير في الحضور، و انخفاض نسبة شكاوي العاملينمما يترنب عليــه

$$
\text { تحقيق الأهداف المنشودة. (') }
$$

و هكذا تعد العلاقات الإنسانية بمؤسسات رياض الأطفال عنصر أساسـي لنجاحها في تأدية وظائفها، و عامل ضروري لانسجام العــاملين وتعـاونهم فـي تحقيق أهدافها، وشرط من شروط الصحة النفسية و الطمأنينة، و الرضا.

\section{ثانياً:نتائج البحث}

توصل البحث الحالي إلى مجموعة من النتائج أبرزها ما يلي:

(أ) نقاط القوة بالمُّناخ التتظيمي لمؤسسات رياض الأطفال

ا- تحرص إدارة الروضة علــى وجــود قنـــوات اتـصـال مفتوحسـة فــي

جميع الاتجاهات بين العاملين بمؤسسات رياض الاطفال عبـر صــفـات التو اصل الاجتماعي حيث يتم فيها تبــادل الــرؤى و الأخبــار و الــدعوة للاجتماعات.

Y- تبت المعلمات بمؤسسات رياض الأطفــال فـــي الأطفــال روح العمـلـ الجماعي، فتحرص المعلمات على إثـاعة جو من الألفة والإخــاء داخــلـ الروضة بين جميع الأطفال. (') أماني عبد الفتاح علي:مهار ات الاتصـال و التفاعل و العلاقات الإنسانية، القاهرة، مكتبــة الأنجلــو

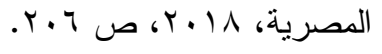

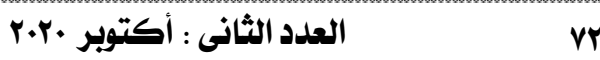


(ب) نقاط الضعف بالمُناخ التنظيمي لمؤسسات رياض الاطفال ب- تذني الأجور و الرو اتب لمعلمات رياض الأطفــال بمـــا لايتتاســب مــع طبيعة العمل و الجهد المبذول منهم مع قلة الحو افز و المكافات الممنوحـــة لهم ع - ربط ميز انية الروضة بميز انية المدرسة داخل حساب موحد مما يتزتـبـ عليه صعوبة الصرف على الروضة. ه- ضعف التعاون بين إدارة الروضة وأوليــاء الأمــور و أفـــر اد المجتمــع الخارجي المحيط بالروضة. ثالثاً:تصور مستقبلي لتحقيق جودة المُناخ التتظيمي بمؤسسـات ريـــاض الأطفال في ضوء الاتجاهات التربوية المعاصرة في ضوء ما توصّل إليه البحث الحالي من نتائج مسـن خــلال الإطـــار

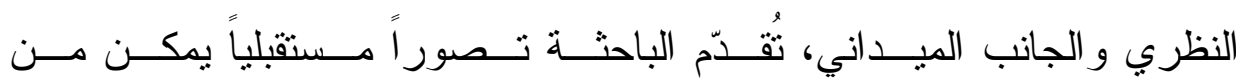

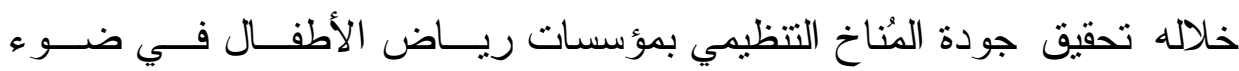
الاتجاهات التربوية المعاصرة، ويتطلب ذلك العمـلـ الهــادف عبــر مجموعـــة من المر احل المتر ابطة، وبذلك فإن رسم المعالم الأولية لهذا التصور يمكـنـ أن

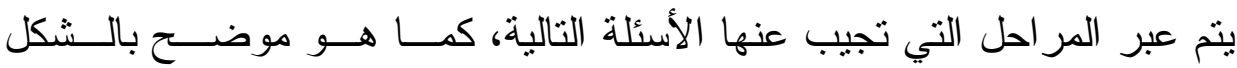

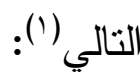

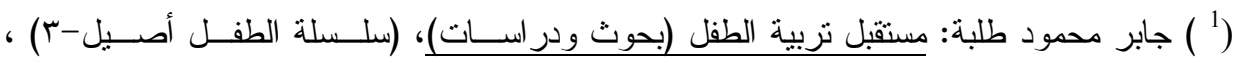

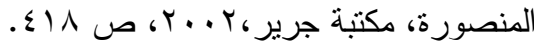

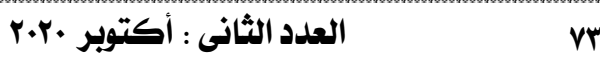

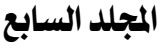




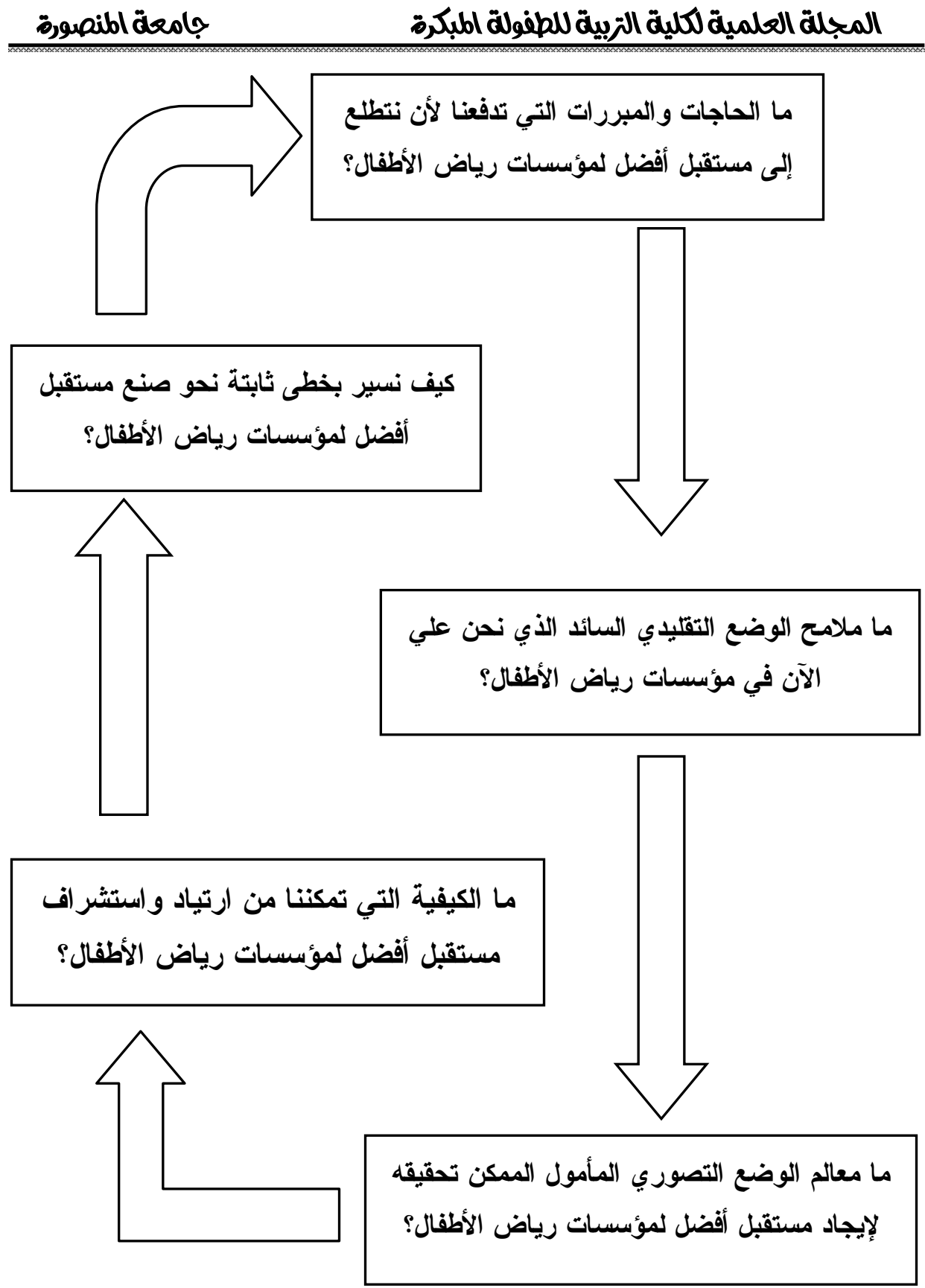

شكل (1) مراحل تكوين المعالم الأولى للتصور المقترح لرياض الأطفال

r.r. المجلد السابع


وفي ضوء الشكل السابق يمكن تقديم تصوراً مستقبلياً لتحقيق جودة المُناخ

التتظيمي بمؤسسات رياض الأطفال في ضوء الاتجاهات التربويـــة المعاصــرة

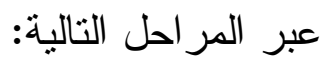

(أ) الحاجات و المبردرات الدافعة للتطلع إلىى مستقبل أفضل لمؤسـسـات ريسـاض

الأطفال

نظر اً لأهمية الدور الذي تلعبه مؤسسات رياض الأطفال، فلابد أن يتـــو افر

لها جهاز إداري ناجح يسعى لتحقيق الأهداف المنشودة بالكفاءة المطلوبة، ومسـن هنا ظهرت الحاجة لإيجاد مناخ تتظيمي فعال يوفر العلاقات الإنسانية الجيدة بين

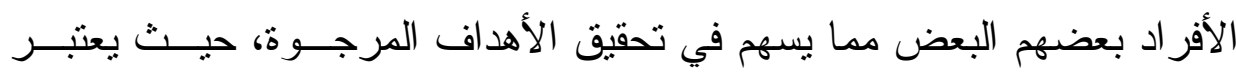

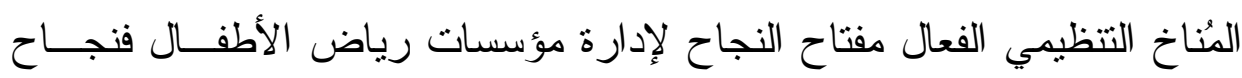

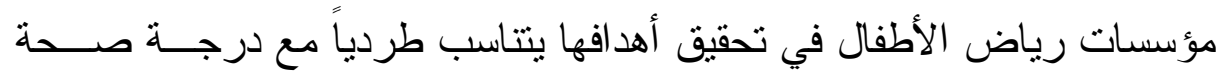

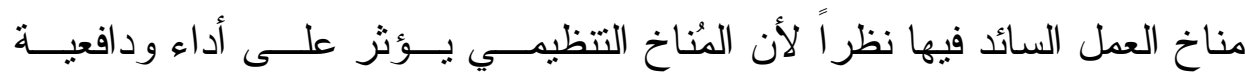

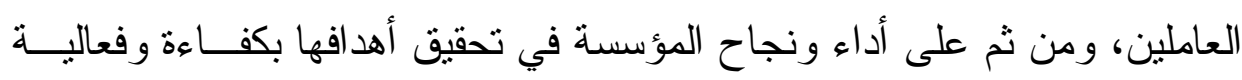
داخلية وخارجية.

\section{(ب) ملامتح الوضع التقلبدي السائد بمؤسسات رياض الأطفال}

تتطلب الرؤية المستقبلية لتطوير المُنــاخ التظظيـــي بمؤســسات ريــاض

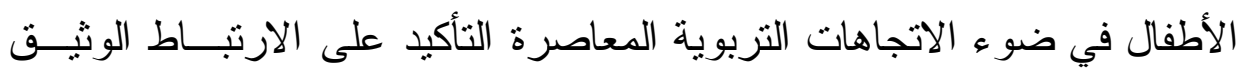

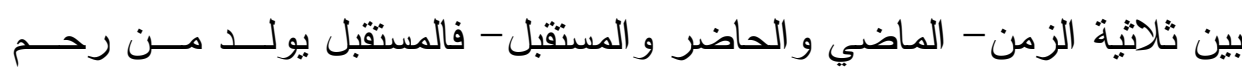

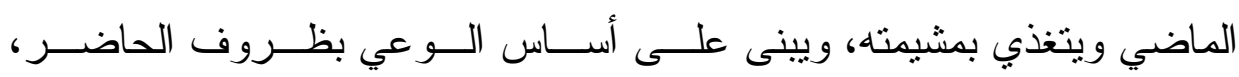

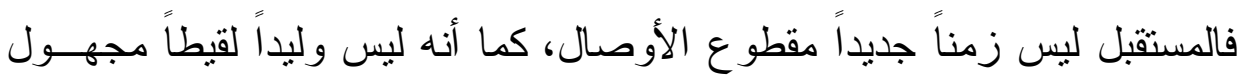


النسب وفاقد الأبوين، ولكن المستقبل هو ابن شرعي للحاضر وحفيـــ طبيعـي

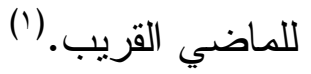

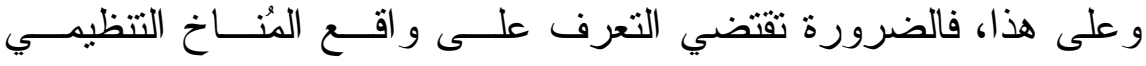

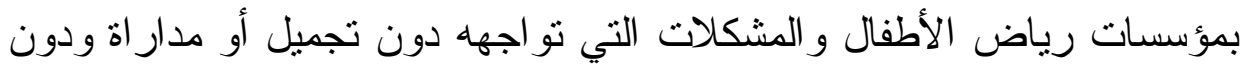

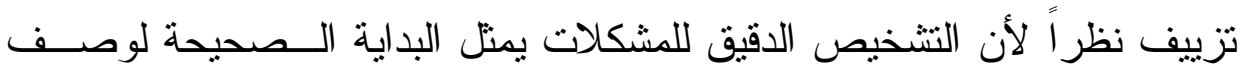
الأدو اء المناسبة لعلاج هذه العقبات التي تلف بخناق هذا الوضع التقليدى السائد. (ج) ملامح الوضع التصوري المأمول الممكن تحقبقه لإيجاد مـستقبل أفـضل لمؤسسات رياض الأطفال

إن التصور المستقبلي الذي تريده الدراسة الحالية لتطوير المُناخ التنظيمي

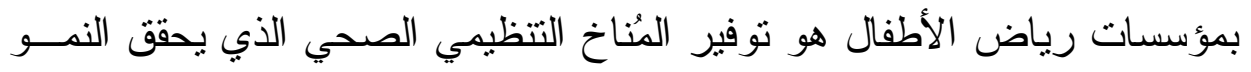

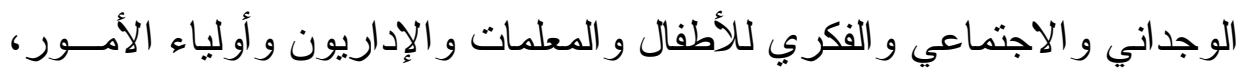
فهنالك حاجة ماسة لإيجاد مُناخ تتظيمي فعال يوفر العلاقات الإنسانية الجيدة بين

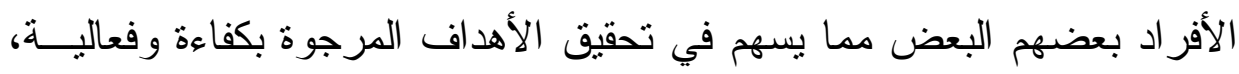

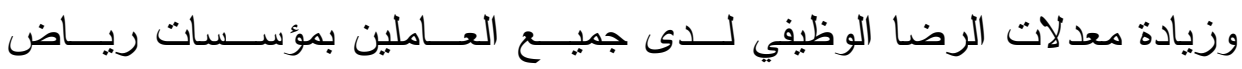

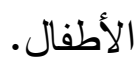

(د)(الكبفية التي تمكنتا من ارتباد و استثر اف مستقبل مؤسسات رياض الأطفال إن ارتياد مستقبل مؤسسات رياض الأطفال بتوقف على الكيفية التي يــنت

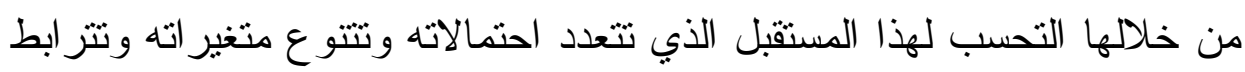

(1) جابر محمود طلبة: المرجع السابق، ص ص 9 (1)-. بــ.

r.r. المجلد السابع


مكوناته، ويتضمن هذا التصور أهدافاً ومنطلقات وبعض الأسـس علــى النحسـو التالي:

$$
\text { 1- أهداف التصور المستقبلي }
$$

يتمثل الهدف الرئيسي للتصور في محاولة تطوير المُناخ التنظيمسي بمؤسـسـات رياض الأطفال في ضو اء الاتجاهات التربوية المعاصرة.

$$
\text { ץ - منطلقات ومستلمّات التصور المستقبلي }
$$

• المُناخ التتظيمي الصحي يحقق النمو الوجداني و الاجتمــــي و الفكـــري

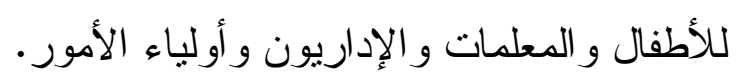

و وجود علاقة وثيقة بين مُناخ مؤسسات رياض الأطفال ودرجة نجاحهــا،

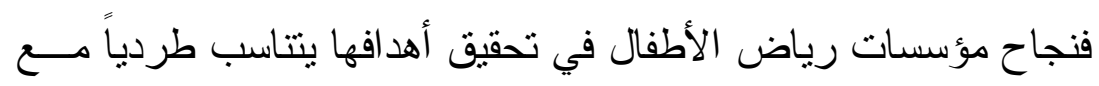
درجة صحة مُناخ العمل السائد فيها.

يمثل المُناخ التتظيمي شخصية مؤسسة رياض الأطفال بكل أبعادها حيث

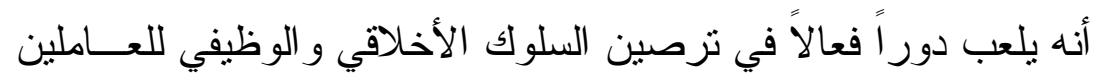
من ناحية، وتتكيل وتعديل وتغيير القيم و السلوك من ناحية أخرى.

$$
\text { r- الأسس التي يرتكز عليها التصور المستقبلي }
$$

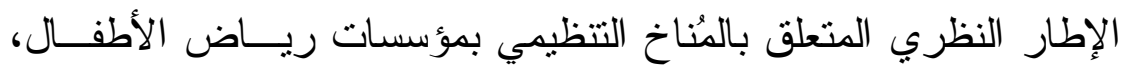

$$
\text { ومعايير الجودة و الاعتماد، و الاتجاهات التربوية المعاصرة. }
$$

نتائج الدراسة الميدانية للوقوف على و اقع المُناخ التظظيـــي بمؤسـسـات رياض الأطفال، و المشكلات التي تو اجهه، وسبل التظلّب عليها. 
(م) كيفية السبر بخطى واثقة نحو صنع مستقبل أفـضل لمؤسسـات ريساض

الأطفال

تمثل هذه المرحلة مرحلة التنفيذ الفعلي لتحقيق التصور المستقبلي لتطــــير

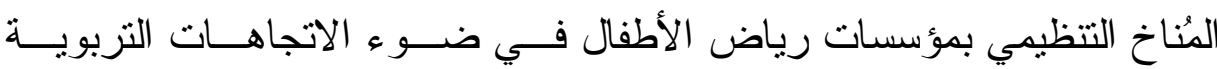
المعاصرة، وتتضمن متطلبات التصور المستقبلي و آلياته.

وتحاول البحثة عرض بعض منطلبات التصور المستقبلي و آلياته فيما بلي: 1- بالنسبة للهيكل التنظيمي بمؤسسات رياض الأطفال

ينبغي أن يتو افر في الهيكل التنظيمي بمؤسسات رياض الأطفال ما يلي:

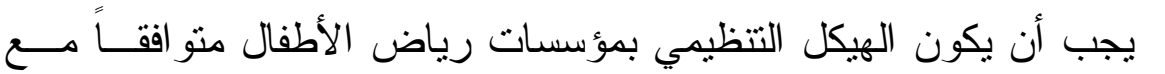

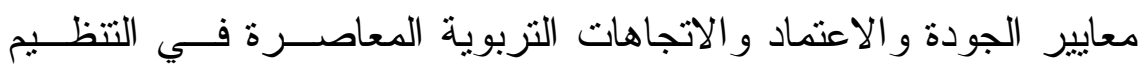
الإداري مع ضرورة الاستتاد إلى أحدث النظريات الإدارية. • يجب أن يتو افق الهيكل التتظيمي بمؤسسات رياض الأطفال مــع طبيعــة

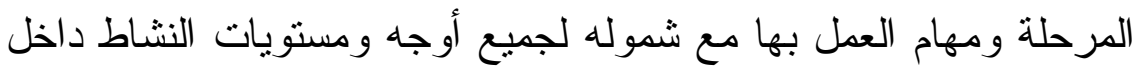
تلاك المؤسسات.

r - بالنسبة للقيادة بمؤسسات رياض الأطفال ينبغي عند اختيار قادة مؤسسات رياض الأطفال أن يكـــن لــــي القائــــ

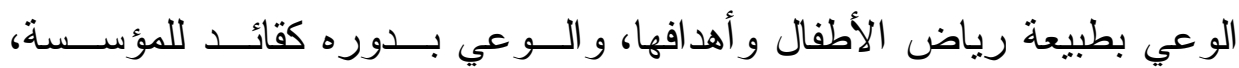
ومتطلبات القيام بهذا الدور على أن يكون لديه القدرة مع زملائه على صـياغة الاطية رؤية ورسالة الروضة، قادر على إقامة علاقات إنسانية قوية بينه وبــين كافـــة

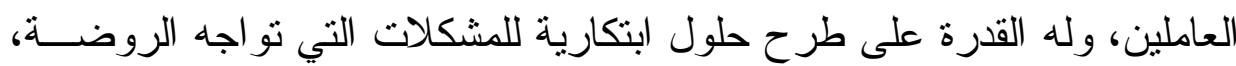

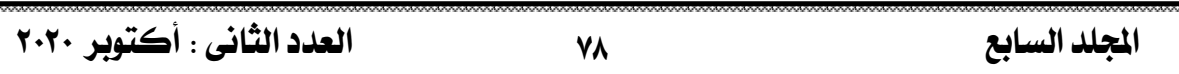


ويدعم التوجهات الابداعية و الابتكارية في العمل، ولن يتأنى ذلك إلا من خــلد ما يلي:

تشتيع معلمات رياض الأطفال على الالتحاق بالدر اسات العليــا و إعـــداد

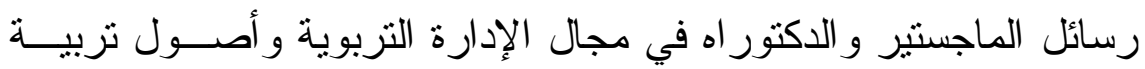
الطفل و اعتبار ذلك من شروط تولي الإدارة بمؤسسات ريــاض الأطفــال مع التركيز على الالتز ام الخلقي قبل الالتز ام العلمي. إصدار تنشريع يحدد نظم اختبار قادة مؤسسات رياض الأطفال، ويكــون

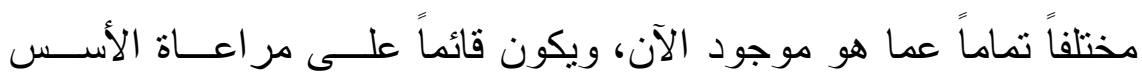
العلمية الحديثة في القيادة.

r- بالنسبة للبيئة المادية بمؤسسات رياض الأطفال ينطلب تطوير البيئة المادية بمؤسسات رياض الأطفال لنطوير المُناخ النتظيهـي

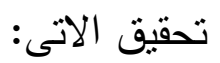

م تخصيص ميز انية خاصة بالروضات بعيداً عن ميز انية المدرسة عامــة،

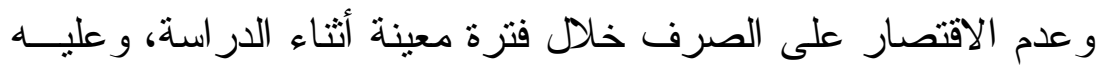

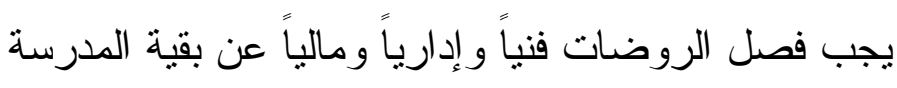
زيادة الرتب الذي تنقاضه المعلمة ليتناسب مع الجهد المبذول في العمل. ع - بالنسبة للعلاقات الداخلية بمؤسسات رياض الأطفال يتوقف تحسين بيئة العمل و الحصول على علاقات عمل جيدة بين العاملين

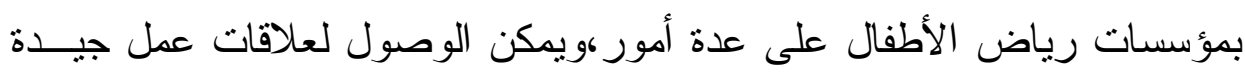
بين العاملين بمؤسسات رياض الأطفال وذلك بتحقيق ما يلي: 
•تنظيم الأنشطة و الفعاليات التي من شــأنها أن توثــق العلاقــات الإنــسانية و الاجتماعية بين العاملين بمؤسسات رياض ولفئل الأطفال.

•مر اعاة الظروف الإنسانية و الاجتماعية التي قد نطر أ على بعض العساملين، و استخدام أساليب إدارية حديثة بتلك المؤسسات.

ه - بالنسبة للعلاقات مع البيئة الخارجية بمؤسسات رياض الأطفال

لتقعيل العلاقة بين مؤسسات رياض الأطفال و المجتمع الخــارجي لتطــــير

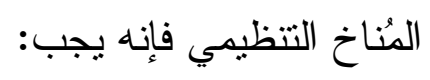

• ألا يكون هناك أيه حو اجز تحول بين أولياء الأمور و المشاركة في متابعة

$$
\text { أطفالهم. }
$$

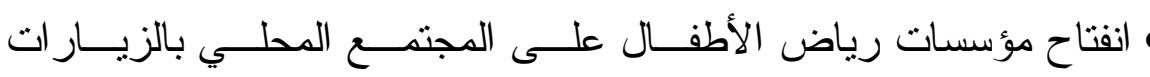

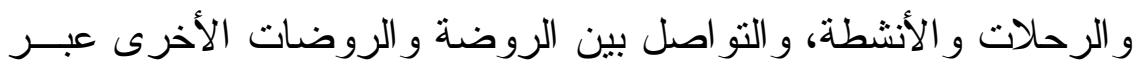

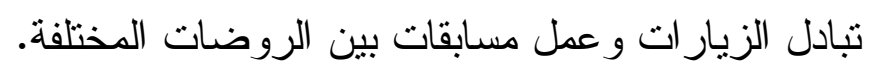

\section{توصيات البحث}

\section{تتمثل أهم توصيات البحث فيما يلي:}

1- تعميق مبدأ العلاقات الإنسانية و التأكيد على أهمية العمل بروح الفريـق،

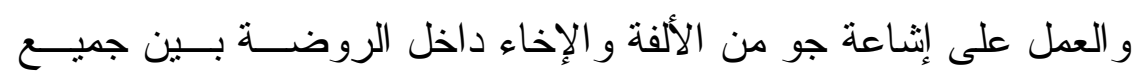

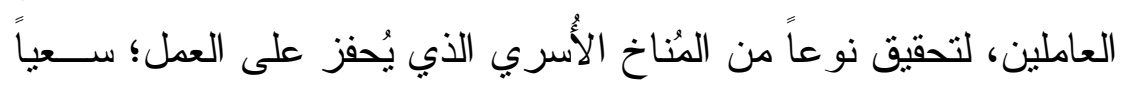

$$
\text { ور اء الارتقاء بمستوى العملية التعليمية. }
$$

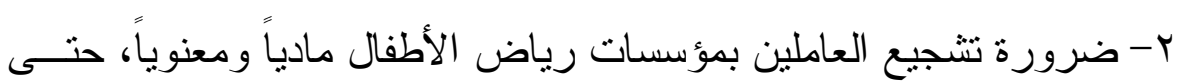
يزداد حماس العاملين، ومن ثَّم يزداد العمل، و الإبداع، و الابتكار . 


\section{قائمة المراجع}

\section{أولاً: المراجع العربية}

ا- أحمد إير اهيم أحمد: الجوانب السلوكية في الإدارة المدرسـية ، القــاهرة،

$$
\text { دار الفكر العربي، . . - . ب. }
$$

ץ- أحمد فاروق على الزميتي: "تصور مقترح لتطـــوير مؤسـسـات ريـــاض الأطفال بجمهورية مصر العربية في ضوء بعـض اتجاهــات التطــــرير

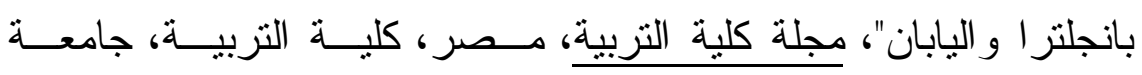

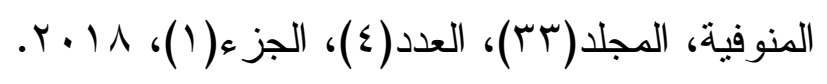

ب- فتحي عبد الرسول محمد: الإدارة التربوية في بعض المؤسسات التعليمية،

$$
\text { دسوق، دار العلم و الإيمان للنشر و التوزيع، } 10 \text { ـ ب. }
$$

ع- أميرة عبد الحميد أحمد شهبة: معوقات تحقيق الفعالية التعليمية بمؤسسات

$$
\text { رياض الأطفال علي ضوء وثثقة معايير الجودة (در اسة ميدانية بمحافظة }
$$

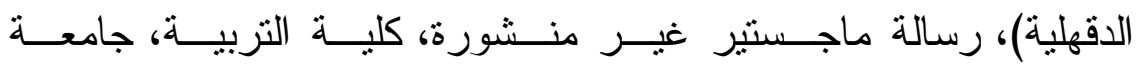

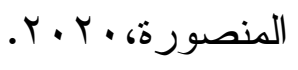

ه- أميرة عبد الرقيب محمد عقيل: تصور مفترح لتطـــوير إدارة مؤسـسـات رياض الأطفال بالجمهورية اليمنية في ضوء مدخل إدارة الجودة الثاملة، رسالة ماجـستير غيــر منـشورة، كليــة ريــاض الأطفــال، جامعـــة

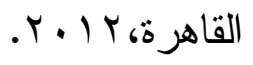

צ- جابر محمود طلبة: مستقبل تربية الطفل (بحــوث ودر اســات)، (سلـسلة

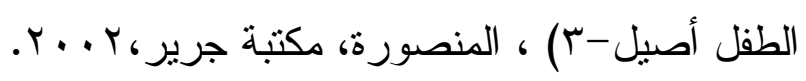


:الانتقال الفعال إلى رياض الأطفال، (سلـسلة الطفـلـل $-\gamma$

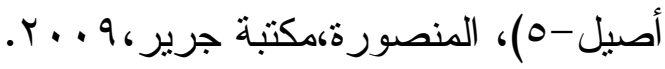

1- رضا مسعد السعيد وأحمد ماهر عبد الحميد الباز : معايير الجودة الـشاملة في رياض الأطفال، الإسكندرية، دار التعليم الجامعي، • ( • بـ. 9- صلاح زهران الخولي: مر اكز المعلومات ودور ها في صنع و اتخاذ ودعر

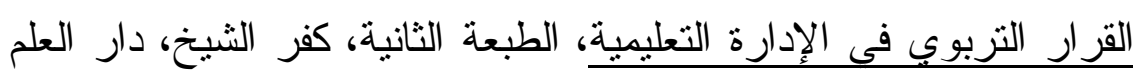

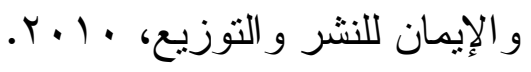

• 1- عاطف عوض:"تحسين المُناخ التنظيمي في الجامعات مدخل لتطوير أداء

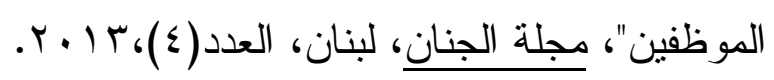
1ا- عبد التواب عبد اللاه عبد التواب: "معوقــات تطبيــق معــيير الجــودة

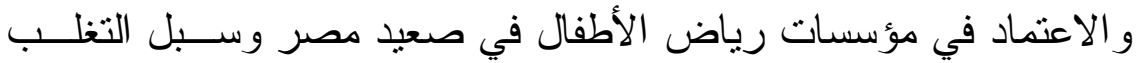
عليها"، المؤتمر الدولى الأول لكلية رياض الأطفال - جامعة أسيوط (بناء

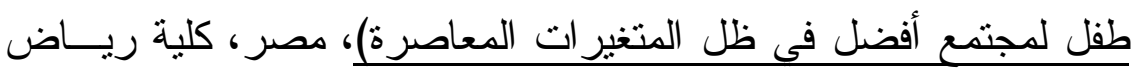

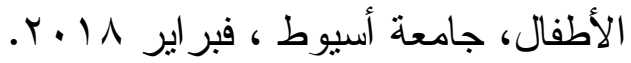

r ا-عبيد بن عبد اله السبيعي:"المُناخ التنظيمي الداعم لضمان الجودة :دراسة

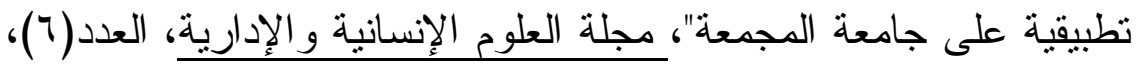
$. r \cdot 1 \leq$

برا- عبد الخالق فؤاد محمد عبد الخالق ومحمد محمود محمـــعلي: مــدخل لرياض الأطفال، الدمام ،مكتبة المتنبي ،1. . . r. 
ع ا - فاروق عبده فيليه والسيد محمد عبد المجيد:السلوك التنظيمي فـى إدارة

المؤسسات التعليمية،عمان،دار المسيرة للنشر و التوزيع و الطباعة، ه . . . .

10-فتحي عبد الرسول محمد: الإدارة التربويــة فـي بعـض المؤسـسـات التعليمية، دسوق، دار العلم و الإيمان للنشر و النوزيع، 10 ـ.ب.

7 ا - لمياء أحمد عثمان ومروة أحمد التهامي: "نشر ثقافة الجــودة و الاعتمــاد التربوي لتحقيق الفعالية التتظيمية بمؤسسات رياض الاطفــال"، المـــؤتمر الدولى الأول لكلية رياض الأطفال -جامعة أسيوط (بنـاء طفــل لمجتمـــع

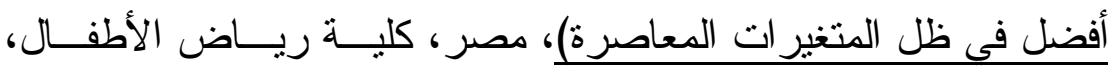

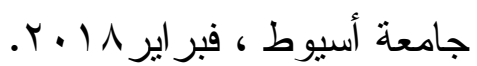

IV

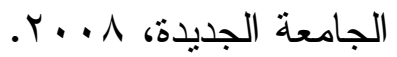

1 ا - منى محمد الهاجري:"در اسة تحليلية لإدارة رياض الأطفال فــي اليابـان وكيفية الإفادة منها بدولة الكويت"، مجلة كليــة التزبيــة، مــصر ، كليــة

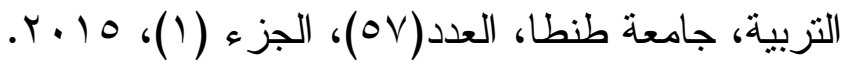

9 ا - نبيل سعد خليل: إدارة الجودة الشاملة و الاعتماد الاكاديمى في المؤسسات

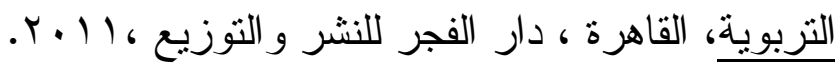

\section{ثثانياً: المراجع الأجنبية}

20-Ann Taylor Allen :" The Kindergarten in Germany and the United States, 1840-1914: A Comparative Perspective", History of Education, Vol.(35), Iss.(2), 2006. 
21-Edric L.Spruill: A Correlation Analysis Relating Organizational Climate to Employee Performance : A Case Study (PHD),University of Phoenix, 2008.

22-Sarah E. Dennis: " Reexamining Quality in Early Childhood Education: Exploring the Relationship Between the Organizational Climate and the Classroom", Journal of Research in Childhood Education, Vol.( 27), 2013.

23-J.ClasienDe Schipper \& Louis W.CTavecchio : Goodness-of-fit in Center day Care; Relations of Temperament, Stability, and Quality of care with the Child's Adjustment, Center for Child and Family Studies, Leiden University, 2004. 